\title{
Multidimensional electrochemical imaging in materials science
}

\author{
Sabine Szunerits • Sascha E. Pust • Gunther Wittstock
}

Received: 15 February 2007 /Revised: 8 May 2007 / Accepted: 10 May 2007 /Published online: 30 June 2007

(C) Springer-Verlag 2007

\begin{abstract}
In the past 20 years the characterization of electroactive surfaces and electrode reactions by scanning probe techniques has advanced significantly, benefiting from instrumental and methodological developments in the field. Electrochemical and electrical analysis instruments are attractive tools for identifying regions of different electrochemical properties and chemical reactivity and contribute to the advancement of molecular electronics. Besides their function as a surface analytical device, they have proved to be unique tools for local synthesis of polymers, metal depots, clusters, etc. This review will focus primarily on progress made by use of scanning electrochemical microscopy (SECM), conductive AFM (C-AFM), electrochemical scanning tunneling microscopy (EC-STM), and surface potential measurements, for example Kelvin probe force microscopy (KFM), for multidimensional imaging of potential-dependent processes on metals and electrified surfaces modified with polymers and self assembled monolayers.
\end{abstract}

Keywords SECM · C-AFM · Polymer · Metal ·

Self assembled layers $\cdot$ Imaging

S. E. Pust $\cdot$ G. Wittstock $(\bowtie)$

Faculty of Mathematics and Science,

Center of Interface Science (CIS),

Department of Pure and Applied Chemistry and Institute

of Chemistry and Biology of the Marine Environment,

Carl von Ossietzky University of Oldenburg,

26111 Oldenburg, Germany

e-mail: gunther.wittstock@uni-oldenburg.de

S. Szunerits $(\square)$

Laboratoire d'Electrochimie et de Physicochimie

des Matériaux et des Interfaces (LEPMI), CNRS-INPG-UJF,

1130 rue de la piscine, BP 75,

38402 St. Martin d'Hères Cedex, France

e-mail: sabine.szunerits@lepmi.inpg.fr

\section{Introduction}

Materials science emerged as an independent interdisciplinary science in the 1950s. It traditionally combines aspects of metallurgy, polymer science, ceramics, chemistry, and chemical and electrical engineering. Chemistry and physics contribute to the field by providing a microscopic understanding of new materials and rational rules for their design. Scanning probe methods have emerged as appropriate new analytical tools for localized investigation of the chemical, electrical, and other physical properties of materials and for creation of artificial materials on the microscale and nanoscale. The general concept of scanning probe microscopy (SPM) is use of a sharp probing tip to scan a sample in close proximity to its surface to obtain spatially resolved information about its chemical, physical, and topographical nature [1]. Although all SPM techniques have this basic principle in common, the used interaction between probe and sample can be quite different, and the specific experimental arrangement will therefore depend on the interaction exploited. If electrical current is to be measured, the need for a conducting tip and for a device to control potential, which implies a potential of some sort between probe and sample, is ultimately needed. The main current-based imaging techniques are electrochemical scanning tunneling microscopy (EC-STM), scanning electrochemical microscopy (SECM), Kelvin probe force microscopy (KFM), and conductive atomic-force microscopy (C-AFM) (Fig. 1).

Without a doubt, with the invention of scanning tunneling microscopy (STM) by Binnig and Rohrer [2] in 1982 a new tool was available for high-resolution imaging of conducting surfaces. STM is, in this respect, used for direct imaging of the density of states at surfaces with atomic resolution and to follow the dynamic of surface processes $[3,4]$. It was 
Fig. 1 Schematic representation of measuring probes for a ECSTM, b KFM, and c SECM. d Schematic arrangement of an AFM instrument with C-AFM extension a

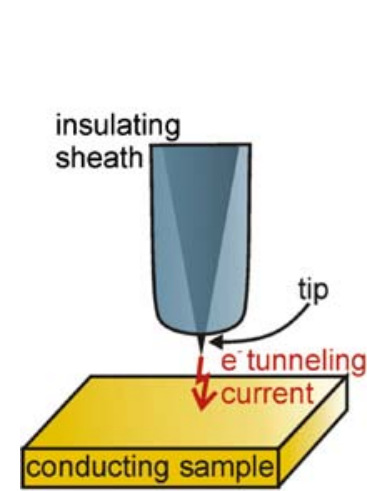

b

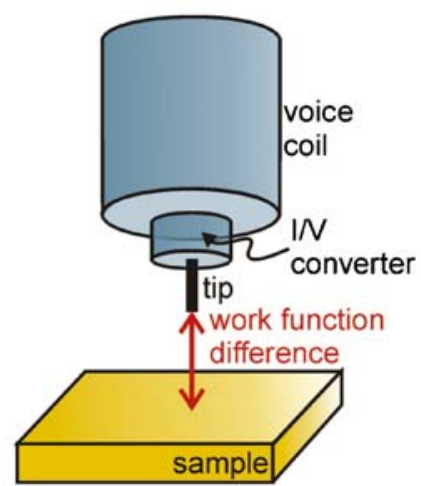

c

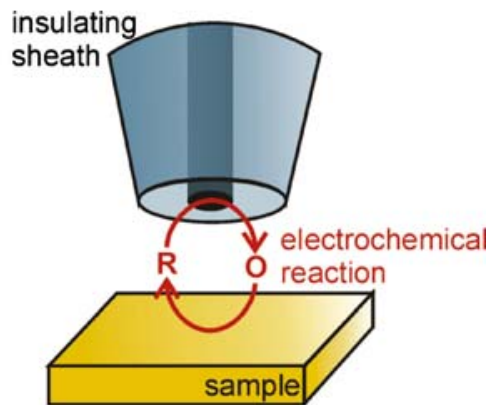

d

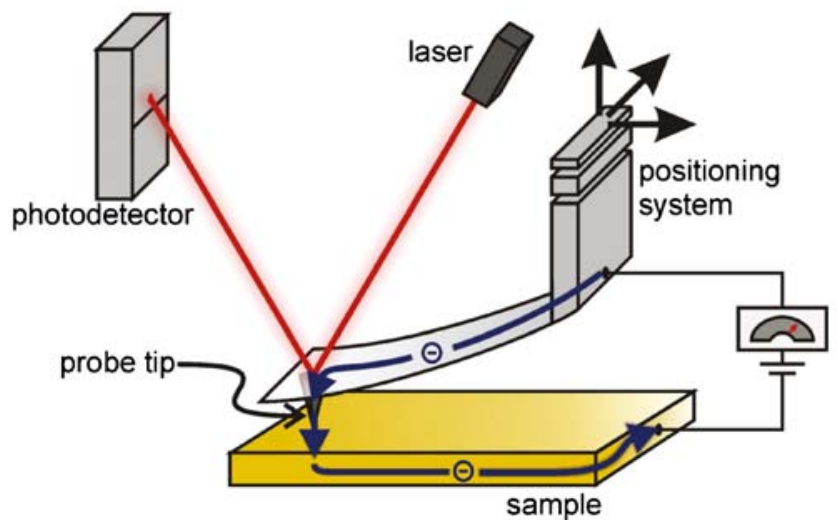

only a few years after this that STM could be performed on liquids and in electrochemical cells under potentiostatic or galvanostatic control [4-6] (Fig. 1a) and found applications in catalysis research [7], for electrodeposition studies of metals and conductive polymers [8], for investigation of morphology changes resulting from electrochemical treatment [9], and for corrosion studies [9, 10]. Practical details of how to perform EC-STM are extensively described in the literature, to which the reader is referred [4, 10-16].

Although STM is used more frequently than AFM for atomic-level imaging, AFM does have some obvious advantages. In particular, when atomic-force microscopy is used in combination with a conductive tip (C-AFM), it can provide functional information about samples containing conducting and insulating regions [17-21]. Topographic and current images can be obtained simultaneously for a variety of systems, thus providing information about the distribution of conducting islands surrounded by insulating areas and relationships between structural features and electrical properties on the nanometer scale that are impossible to obtain by EC-STM [22, 23]. To determine local resistivities of a metal, a potential difference is applied between a conducting tip (Pt, $\mathrm{Pt} / \mathrm{Ir}$, Ti, doped diamond) that is in mechanical contact with the sample surface (Fig. 1d). The recording of $\mathrm{I}-\mathrm{V}$ curves by measuring the current as a function of the applied voltage makes C-AFM an especially useful tool for local characterization of conducting and semiconducting materials. Electron transport through single molecules [24], self assembled monolayers (SAM) [25], carbon nanotubes [26], and fuel cell membranes [27] has been investigated in parallel with imaging. Although the requirement for mechanical contact between probe and sample makes imaging difficult on soft (biological) materials, the high resolution of the obtained images often compensates for this handicap, and C-AFM was recently used to show conductance switching in nanowires composed of tobacco mosaic virus conjugated with platinum nanoparticles [28].

C-AFM shares many instrumental and theoretical details with Kelvin probe force microscopy (KFM), a powerful tool for measuring changes in contact potential difference between probe and sample with high accuracy in a nondestructive measurement [1, 29] (Fig. 1b). Several reviews and research articles during the last two decades show KFM has been applied in biological research [30-32], studies at polymer-metal interfaces [33-35], and, especially, in corrosion science [36-43]. 
Scanning electrochemical microscopy (SECM) complements STM and C-AFM because it probes interfacial processes (chemical reactions at liquid-gas, liquid-liquid, and liquid-solid interfaces) with high spatial resolution and well-characterized mass transport [44, 45] (Fig. 1c). SECM is an attractive tool for chemical identification of redoxactive ions and molecules, for investigation of surface kinetics, and for identification of regions of different electrochemical properties and chemical reactivity. Since the first SECM experiments by Engstrom et al. [46] and Bard et al. [6] in 1986, the number of groups using this technique has increased steadily. Several comprehensive reviews [44, 47-58], books [45, 59], and book chapters [60-67] are available about this technique; the reader is referred to these for detailed information about instrumental set-up, concept, measurement modes, and data interpretation. Besides approaches combining SECM with other scanning probe techniques, for example EC-STM [68-71] and AFM [7277], the work of Schuhmann et al. [78, 79] popularized the use of a shear-force-based distance-control mechanism in the SECM community.

The SECM can be operated in two imaging modesgeneration-collection (GC) mode and feedback (FB) mode. For measurements in FB mode the bulk solution contains the oxidized or reduced form of a quasi-reversible redox couple as a mediator. It is converted at the ultramicroelectrode (UME), under diffusion-controlled conditions, leading to a diffusion-controlled current $i_{\mathrm{T}}$. This current increases or decreases as the UME approaches the sample, depending on the rate of mediator recycling at its surface (Fig. 2a). In the GC mode the working solution does not contain $\mathbf{a}_{(1)}$

(2)

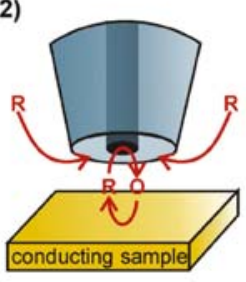

b

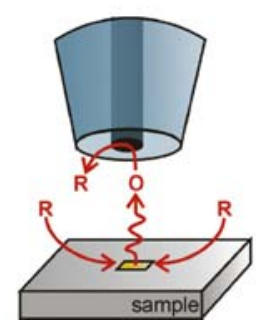

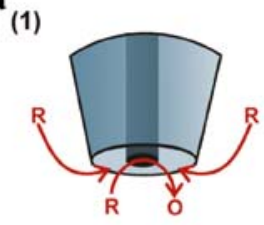

(3)

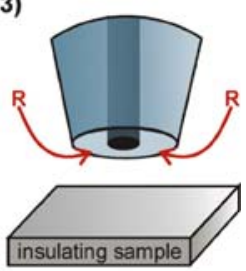

compounds that may participate in an electrochemical reaction at the potential of the UME. Redoxactive compounds that are generated or released from active regions of the sample can then be monitored by the UME (Fig. 2b).

The objective of this review is to show what electrochemically and electrically based scanning probe microscopy techniques, for example EC-STM, SECM, C-AFM, and Kelvin probe, can offer to materials science. The discussion will primarily focus on:

1. the corrosion of metals and semiconductors;

2. polymer-modified interfaces; and

3. the effect of self assembled monolayers on the electrochemical and electrical properties of conducting substrates.

We will conclude with some perspectives for the future.

\section{Metals}

One topic of great interest in materials science is the stability of a metal against oxidative dissolution. Corrosion research is very important in the development of stable materials that can be used, for instance, in aviation, ship building, civil engineering, and biomedical applications, etc. On most metallic materials a thin layer of oxide prevents ongoing dissolution. In the event of local breakdown of this passive film, active regions can be revealed, leading to pitting corrosion. Although several electrical and electrochemical methods can be used to study the integral attributes of a metal surface, and thus of the passive film, scanning probe microscopic techniques are well suited to investigation of the localized phenomena often responsible for substantial damage to the material. While C-AFM and KFM can be used to study the distribution of conductivity on metallic materials, EC-STM and SECM enable detection of localized reactivity and imaging of on-going corrosion processes. They are thus able to reveal precursor sites which, because of their size, are often not accessible to other experiments. One special aspect of studies of these passive layers is that metal oxides often have semiconducting properties with the metallic substrate itself being a pure conductor. This is especially important for electrochemical studies in which the formal potential of a dissolved reactant, e.g. a mediator in SECM, is relevant to the electronic structure of the metal oxide [80].

SECM is regarded as a very suitable tool for corrosion studies because it can differentiate between active and passive regions of the sample. It does, furthermore, enable quantification of the concentration of a variety of species relevant to corrosion reactions (e.g. $\mathrm{Fe}^{2+}, \mathrm{Fe}^{3+}, \mathrm{H}_{2}$, and $\mathrm{O}_{2}$ ). Identification of precursor sites for pitting corrosion that
Fig. 2 (a) General principle of the feedback mode with the tip far away from the sample (1), with the tip in close proximity to a conducting sample (2) and with the tip in close proximity to an insulating sample (3). (b) General principle of the generation-collection mode 
often result from local damage of the oxide film has been achieved in the sample generation/tip collection (SG/TC) mode on steel [81-85], Ti [86-90], Ta [91, 92], Ni [93], and $\mathrm{Al}[94,95]$ by use of their enhanced kinetics of heterogeneous electron transfer to dissolved components. With SECM, identification of those precursor sites in their passive state is possible because of the nondestructive character of the technique. For a $0.79 \mathrm{~cm}^{2}$ macroscopic Ti/ $\mathrm{TiO}_{2}$ electrode it was estimated with the theory of mass transport through individual pores that $69 \%$ of the current was passing through eleven precursor regions that comprised only $0.1 \%$ of the total area [89]. Basame and White [92] observed that the chemical selectivity of precursor regions on $\mathrm{Ti} / \mathrm{TiO}_{2}$ differs from that on $\mathrm{Ta} / \mathrm{Ta}_{2} \mathrm{O}_{5}$. Whereas $\left[\mathrm{Fe}(\mathrm{CN})_{6}\right]^{4-}$ and $\mathrm{Br}^{-}$have the same reactivity on $\mathrm{Ti} / \mathrm{TiO}_{2}$, precursor sites on $\mathrm{Ta} / \mathrm{Ta}_{2} \mathrm{O}_{5}$ convert $\mathrm{I}^{-}$and $\left[\mathrm{Ru}\left(\mathrm{NH}_{3}\right)_{6}\right]^{3+}$ at clearly different rates.

Garfias-Mesias et al. [90] concluded inter alia from SECM observation of active regions that precursor sites on Ti can be associated with inclusions of other elements, for example $\mathrm{Si}$ and $\mathrm{Al}$. For stainless steel, precursor regions can be associated with $\mathrm{MnS}$ inclusions. A method was developed to follow the progression of pitting near these inclusions by combining SECM, EC-STM, and other microscopic techniques [68]. Paik and Alkire [93] introduced a similar approach for investigation of sulfidic inclusions on $\mathrm{Ni}(200)$. By reaction with $\mathrm{I}_{3}^{-}$that is formed at the UME, sulfur-containing compounds can be detected electrochemically as they are released from such inclusions [96]. This approach was expanded by Lister and Pinhero to measurement of the local electric field strength [83] and to studies using a microelectrode array [97]. Pust et al. [80] used SECM and C-AFM to visualize the local reactivity and conductivity of the native passive film on the biomaterial Ti6Al4V. The phase structure of the material was associated with the electronic properties and electrochemical behavior of the oxide layer (Fig. 3). This not only affects the corrosion properties but is also an important aspect of understanding its remarkable biocompatibility.

Besides observation of precursor sites, SECM also enables local initiation of pitting. By electrochemical reduction of trichloroacetic acid at an amalgamated $\mathrm{Au}$ UME, high concentrations of $\mathrm{Cl}^{-}$ions were generated locally and initiated the formation of active pits on a steel substrate $[98,99]$. The observed current was typical for the formation, growth, and repassivation of an individual pit.

Monitoring of active corrosion by SECM has been realized on a range of materials by identification of locally released species by cyclic voltammetry at the UME or by use of ion-selective potentiometric microelectrodes. The materials investigated include steel [100-102], dental fillings [103, 104], Si [105], Ti [106, 107], alloys [76, 108-113], ZnSe wave-guides [114], organic coatings on a

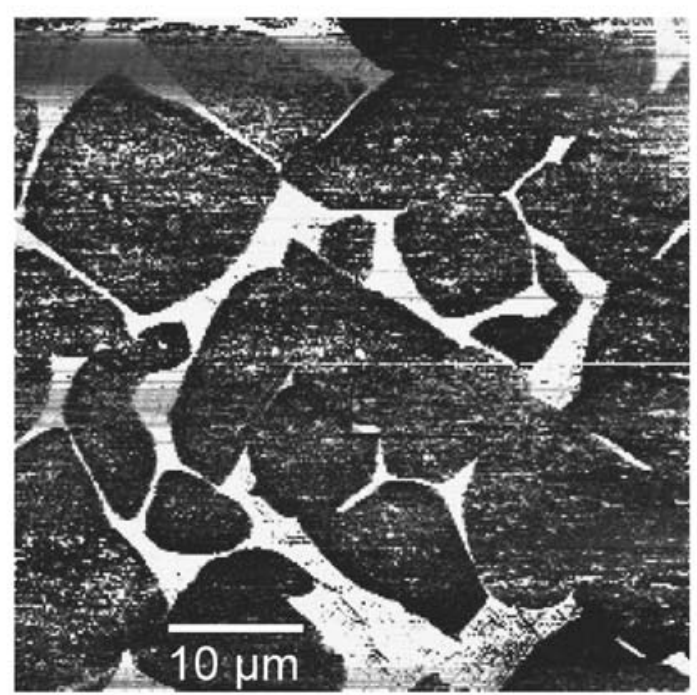

b

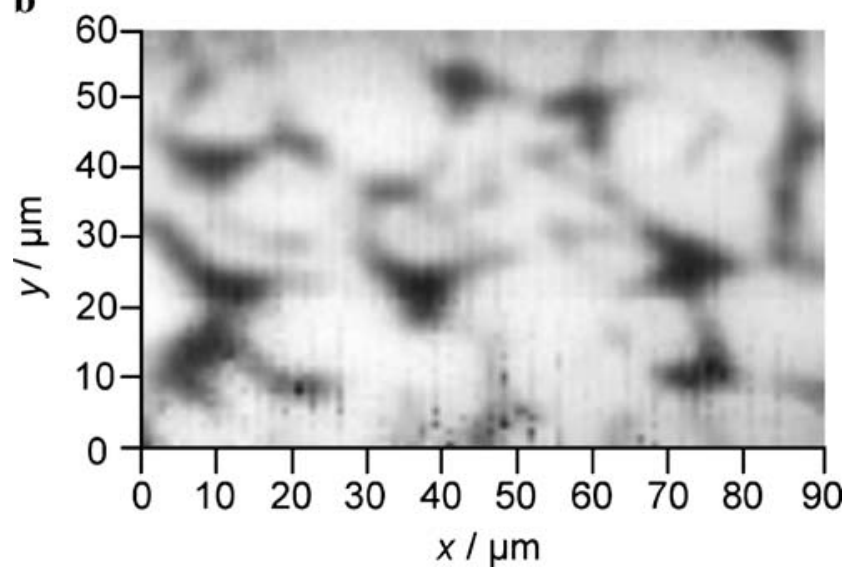

Fig. 3 (a) C-AFM image (bright regions represent high current) and (b) SECM image of the passive film on a coarse-grained model sample of Ti6Al4V (dark regions represent high current). Mediator: $2 \mathrm{mmol} \mathrm{L}{ }^{-1}\left[\mathrm{Ru}\left(\mathrm{NH}_{3}\right)_{6}\right] \mathrm{Cl}_{3}$ in $0.1 \mathrm{~mol} \mathrm{~L}^{-1} \mathrm{KCl}$. (Reprinted, with permission, from Ref. [80]. Copyright 2007, Wiley-VCH)

metallic substrates [115-117], AgI-based ion-selective membranes [118], and composite-based amperometric biosensors [119]. Simões et al. [120] studied the corrosion behavior of an iron/zinc galvanic couple immersed in aqueous sodium chloride solution. The SECM studies were also occasionally enhanced by impedance measurements [111, 115, 121-123], although the reasons for the contrast observed are not always clear and seem to be affected by several factors [122].

EC-STM has also been used to study the passive film on metallic substrates, although the focus was on highresolution (atomic scale) characterization of surface structures and their changes. Zuili et al. [124] observed the dissolution of atomic steps and terraces on $\mathrm{Ni}(111)$ singlecrystal surfaces at a potential $-50 \mathrm{mV}$ below the corrosion potential. They assigned grain sizes and an increase in roughness to coalescence processes and thickness changes 
in the passive film that was anodically grown at different potentials. Studies on $\mathrm{Cu}$ comprise measurements of duplex passive films on $\mathrm{Cu}(111)$ and $\mathrm{Cu}(001)$ [125], studies of the corrosion behavior of underpotentially deposited $\mathrm{Cu}$ and its passivation with a SAM of organomercaptan [126], and observation of the dissolution of a nanocrystalline $\mathrm{CuZr}$ coating [127]. The effect of mercaptan passivation on the cyanide-induced corrosion of $\mathrm{Au}(111)$ was studied by Zamborini and Crooks [128]. Diez-Perez et al. [129] used EC-STM to follow the electrochemical growth of the passive film on freshly polished iron and associated the changes on the surface with the formation of iron hydroxides from $\mathrm{Fe}^{2+}$. Maurice et al. [130] studied nucleation and growth mechanisms and the structure of passive films formed on $\mathrm{Cu}(111)$ surfaces in a basic borate buffer solution. For further details the reader is referred to a comprehensive review by Maurice and Marcus of applications of EC-STM in corrosion science [10].

A major application of the scanning Kelvin probe technique is research on organic coatings that serve as corrosion inhibitors on metallic surfaces. This work has been extensively promoted by Stratmann and coworkers, and several reviews on these studies have already been published [34, 36, 40, 43]. The introduction of a heightregulating mechanism into the scanning Kelvin probe improved the spatial resolution of measurements at buried polymer-metal interfaces [131]. Williams and McMurray have also had success in this field, and have focused their studies on the effects of inhibiting components, for example chromate [132] and $\mathrm{Ce}^{3+}$ [133], on the delamination of poly (vinyl butyral) coatings adhering to the $\mathrm{Zn}$ surface of hotdip galvanized steel. They were able to show that delamination speed was substantially reduced by addition of inhibitors, and attributed this to formation of cathodic oxide or hydroxide films on areas of the $\mathrm{Zn}$ surface already exposed because of delamination. Figure 4 illustrates this for $\mathrm{Ce}^{3+}$ [133]. The scanning Kelvin probe was used to record line scans starting from the point of the defect. Whereas in the uninhibited experiment the reaction front, and thus the delamination, propagates quickly from the defect (Fig. 4a), addition of $\mathrm{Ce}^{3+}$ slows propagation (Fig. $4 \mathrm{~b}$ ). The corrosion potential $\mathrm{E}_{\text {corr }}$ also remains lower, which implies the formation of a passivating film. Besides this work on more or less conventional organic coatings,
Fig. 4 Relationship between local free corrosion potential $\mathrm{E}_{\text {corr }}$ and distance $x$ from defect edge recorded for unpigmented $30-\mu \mathrm{m}$ polyvinylbutyral coatings on hot-dip galvanized $\mathrm{Zn}$ substrate. The electrolyte in contact with the defect is $0.86 \mathrm{~mol} \mathrm{dm}^{-3} \mathrm{NaCl}$. (a) Uninhibited, (b) inhibited with $2.5 \times$ $10^{-3} \mathrm{~mol} \mathrm{dm}^{-3} \mathrm{CeCl}_{3}$. Time key: curve $a=120 \mathrm{~min}, b=$ $240 \mathrm{~min}$, etc. (c) Schematic representation of the corrosiondriven cathodic delamination cell showing correspondence with various regions of the timedependent $E_{\text {corr }}(x)$ profile under conditions where the external electrolyte contains $\mathrm{Ce}^{3+}$. (Reproduced, with permission, from Ref. [133]. Copyright 2002, The Electrochemical Society) a

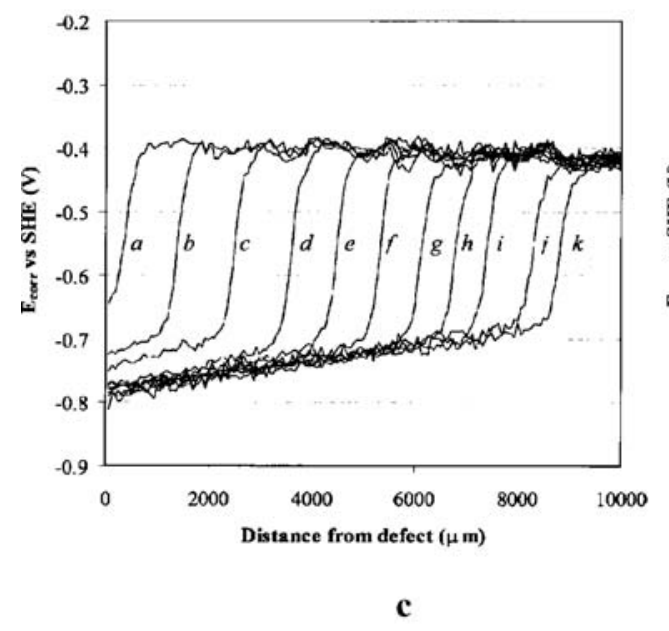

b

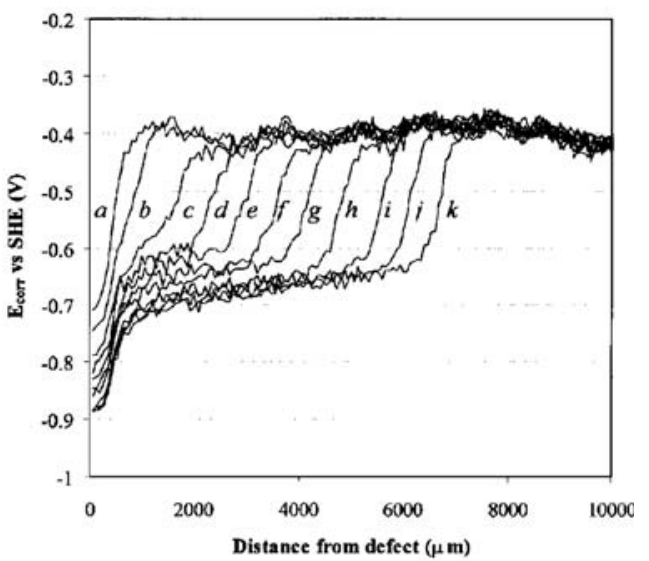

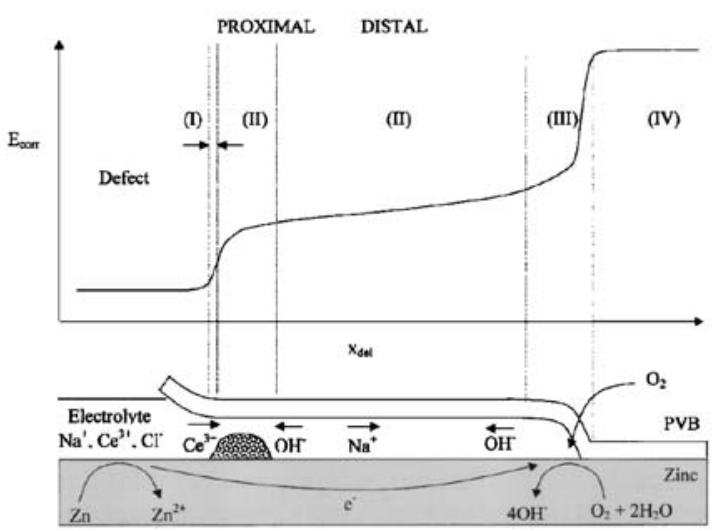


KFM has also been used to visualize latent eccrine fingermarks on metallic surfaces [134]. Zerweck et al. [135] have recently used the scanning Kelvin probe technique to study changes in work function on adsorption of $\mathrm{C}_{60}$ by different metal single crystals.

In the past decade many KFM studies have also been conducted on a broad range of topics in corrosion science, including research on the corrosion behavior of steel [136144], Al [143], $\mathrm{Cu}$ [145-148], Zn [143, 144, 149-152], alloys based on $\mathrm{Al}-\mathrm{Mg}$ [153-164] and $\mathrm{Ti}$ [165], on corrosion protection with rare-earth elements [166] and other inhibitors [167-170], the effect of conversion coatings [171-176], and the effects of heat treatment on material properties [177-179]. Yamawaki et al. [180] used a high-temperature scanning Kelvin probe to measure changes of work function of undoped and $\mathrm{Nb}$-doped $\mathrm{ZrO}_{2}$ and to derive conclusions about the corrosion properties of fuel element cladding. The effect of a blasting treatment on $\mathrm{Cu}$ tubes used in drinking-water installations has also been studied in combination with measurements of the photo effect [181]. Wang and Li [170] examined the mechanical properties of Y-free and Y-containing 304 stainless steel. They showed that $\mathrm{Y}$ enhances the chemical stability and mechanical failure resistance of the passive film on steel by measuring its electronic stability with KFM and by determining the critical load.

The effect of microcracks on the fracture or failure of materials was studied by $\mathrm{Li}$ and $\mathrm{Li}$ [182]. They proposed use of a micro capacitor model to calculate the work function from the geometric properties of microcracks and verified their theoretical considerations with KFM experiments. Jia et al. [160] combined KFM and boundary element method (BEM) simulations to enable understanding the spreading of galvanic corrosion across the surface of the magnesium alloy AZ91D coupled to a steel fastener. They applied a BEM model to simulate galvanic corrosion of specimens immersed in 5\% $\mathrm{NaCl}$ solution (Fig. 5b) and compared these results with their observations (Fig. 5a). From KFM studies they were able to identify microgalvanic cells between the $\alpha$ and $\beta$ phases of the material (Fig. 5c); the size, distribution, and potential differences of these cells may have a significant effect on the total corrosion rate.

One difficulty of C-AFM in studies of metallic surfaces is that the metallic coating on the probe tends to abrade in the course of the measurement. This makes suitable imaging of local conductivity quite complicated. Although commercial AFM probe suppliers recently helped to overcome these difficulties by introducing conductive tips made from doped diamond-like carbon, applications of CAFM on metallic surfaces are still rare. Besides the abovementioned measurements on Ti6Al4V in association with SECM experiments [80], Boneberg et al. [17] performed
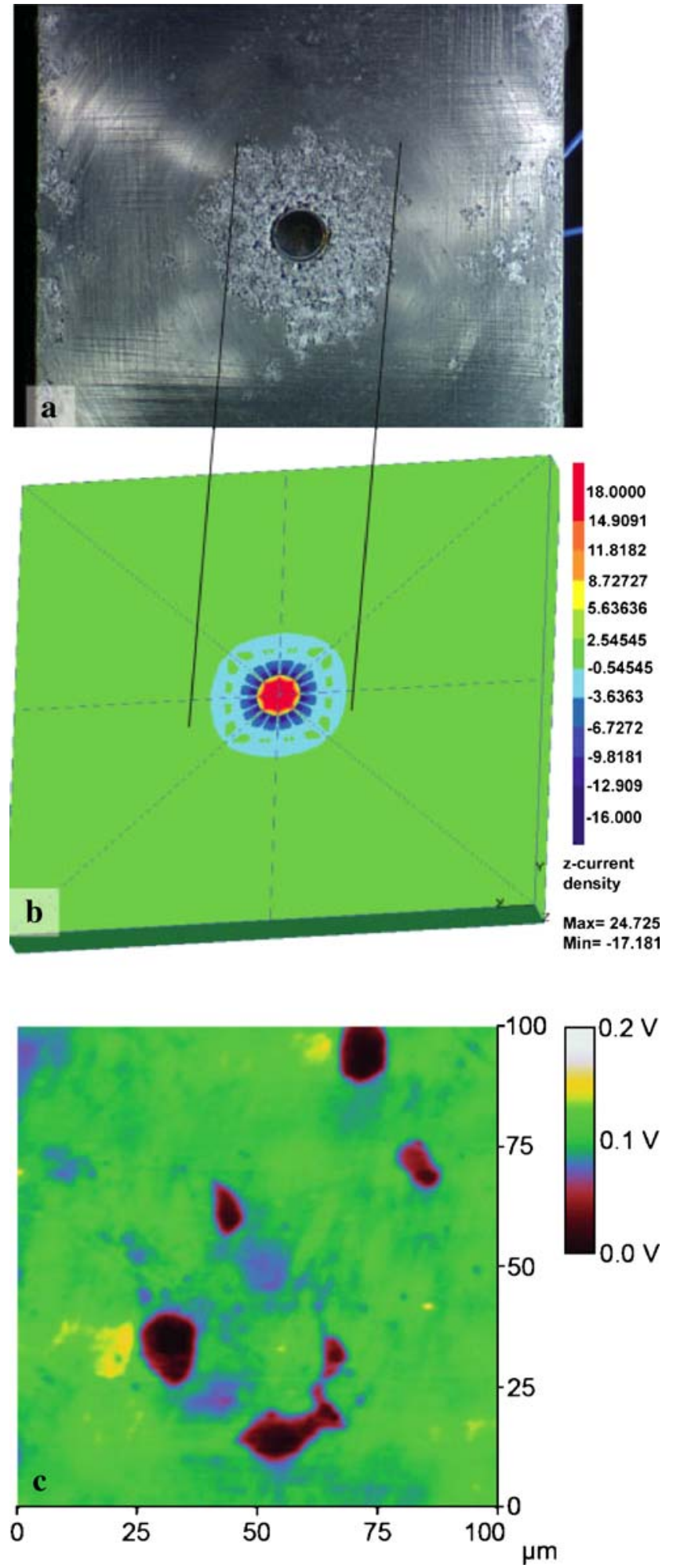

Fig. 5 (a) Experimental immersion test and (b) BEM model of the galvanic corrosion area for a $10 \mathrm{~mm}$ diameter steel cathode on AZ91D after immersion for $48 \mathrm{~h}$ in $5 \% \mathrm{NaCl}$ solution. The extent of galvanic corrosion for the BEM model was estimated from the point at which the galvanic current becomes essentially zero. (c) Representative KFM contact potential difference map of AZ91D after immersion in 5\% $\mathrm{NaCl}$ for $1 \mathrm{~min}$. (Reprinted, with permission, from Ref. [160]. Copyright 2005, Wiley-VCH) 
nanostructuring experiments with $\mathrm{C}$-AFM on a $\mathrm{YBa}_{2} \mathrm{Cu}_{3} \mathrm{O}_{7}$ thin film surface to study corrosion-induced abrasion and to support previous STM experiments. Guessab et al. [183] used this technique to study the advantages of a protective polyacrylonitrile coating on metals at different temperatures and pressures. They proved that the coating itself is covered by a nonadherent and poorly conducting thin film which improves the corrosion characteristics of the material. Investigations on the performance of PEM fuel cells have also been conducted [27].

Although passive layers are important for preventing reactions on the surface of construction materials, catalytically active materials are also based on metals but are optimized to accelerate specific reactions at their surface. This is an important and established topic for scanning probe techniques. In particular, solid-gas interface structures and the dynamics of adsorbed intermediates have been imaged on model samples (usually low-index single-crystal surfaces) by STM with atomic resolution [184]. Real catalysts consist of supported metal nanostructures, operated far from the conditions of model samples, with very complex structure-reactivity relationships that call for the combined application of different scanning probe techniques but at the same time impose severe limitations on the applicability of imaging concepts that are so successful at extended single crystal surfaces. Applications of the current-based imaging techniques considered in this review in basic research on fuel-cell components have been rapidly increasing [69, 185-195]. In general, the morphology of nanostructures is best imaged by EC-STM or AFM whereas local reactivity is obtained by use of the operating principles of SECM in various and still developing configurations [58]. A detailed discussion of this area is a review subject of its own and will not be followed further here.

\section{Polymers}

The synthesis of polymers by chemists in the laboratory led to a real cultural and commercial revolution. Since then, synthetic polymers (e.g. polyethylene, polystyrene, nylon, polyesters) have been exploited extensively as components of a wide variety of commodities, including plastics, rubbers, fibers, adhesives, and surface coatings. Next to synthetic polymers, there is a strong interest in ionically (e.g. polyfluorinated sulfonate polymers) and electronically (e.g. polyacetylene, polyphenylenes, polyaniline, polypyrrole, polythiophene) conducting polymers with many new ideas emerging from the simple observation that these are materials which combine the electronic properties of metals and semiconductors while retaining the processing advantages of polymers. Electronically conducting polymers are an interesting class because of their high electrical conduc- tivity in the oxidized state $[196,197]$. They have been shown to be important materials in a variety of technological systems ranging from chemical sensors, energy-conversion devices, corrosion protection layers, electrochromic devices, molecular-based transistors and memory devices to interconnects and systems for the fabrication of $p-n$ junctions [198-202]. They are particularly appealing because they are prepared by straightforward chemical and electrochemical methods [203] and can switch from an insulating to conducting states by undergoing oxidation reactions [204]. They can, furthermore, be deposited as thin films.

SECM has proved its strength in the investigation of polymer coatings. One of the first investigations was of the ion transfer that occurs on electrochemical switching of redox-active polymers. Through tip/substrate cyclic voltammetry $(\mathrm{T} / \mathrm{S} \mathrm{CV})$, the tip current $\left(i_{\mathrm{T}}\right)$ can be monitored as the potential is cycled to switch the redox state of the polymer film. By setting the tip to a constant potential $\left(E_{\mathrm{T}}\right)$, ejection/ incorporation of ions can be detected and identified. In this way, ejection/incorporation of $\mathrm{Fe}(\mathrm{CN})_{6}^{3-/ 4-}$ at protonated poly(4-vinylpyridine) films and the ejection of $\mathrm{Os}(\mathrm{bpy})_{3}^{3+/ 2+}$ from Nafion coatings was revealed [205, 206]. T/S CV further helped in the detection of proton fluxes during the redox cycling of polyaniline and in differentiating $\mathrm{Cl}^{-}$and $\mathrm{H}^{+}$fluxes [207, 208]. Potentiometric tips have been used to detect $\mathrm{Cl}^{-}$fluxes and provided direct evidence in support of the accepted mechanism for polyaniline oxidation [209]. The anion-exclusion and cation-absorption ratio during electrochemical switching of the polypyrrole film under different experimental conditions has been estimated by use of a UME set at a potential to oxidize $\mathrm{Br}^{-}$[210].

For numerous applications a detailed understanding of charge and mass-transport processes involved in and through polymer coatings on conducting substrates is imperative. These investigations are necessary because charge transport across polymer layers involves several processes that may occur simultaneously, resulting in different overall mechanisms [58]. Because of the nonuniformity of electrically conducting polymers, the situation is even more complex. Charge-transfer kinetics integrated over a large surface are often not representative of a particular region of the polymer film.

Different important mechanisms can be distinguished for the reaction between a polymer-coated electrode and a redox species in solution (Fig. 6). An inert, insulating, and nonpermeable polymer film hinders the diffusion of the mediator to the conducting interface below. Polymeric films might be porous membranes resulting in partially hindered electron transfer at the underlying metal. Only those pores that penetrate the entire film and reach the conducting substrate will cause a signal in SECM feedback mode. For highly porous polymer films supported on conductive substrates, quantification of the molecular permeation rate 
Fig. 6 Schematic diagram of charge and electron transfer through polymer layers and its investigation by SECM. (a) An inert, insulating and nonpermeable film hinders diffusion of the mediator; (b) dissolved redoxactive species reach the support surface through pinholes; (c) the redoxactive species are soluble in the polymer film and diffuse toward the support; (d) dissolved redoxactive species react with a mediator confined within the polymer film; (e) dissolved species exchange electrons with an electronically conducting polymer at the film-electrolyte interface. (Reprinted, with permission, from Ref. [58]. Copyright 2007, Wiley-VCH)

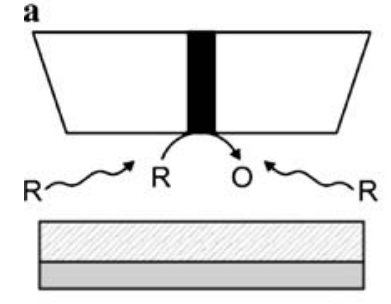

b
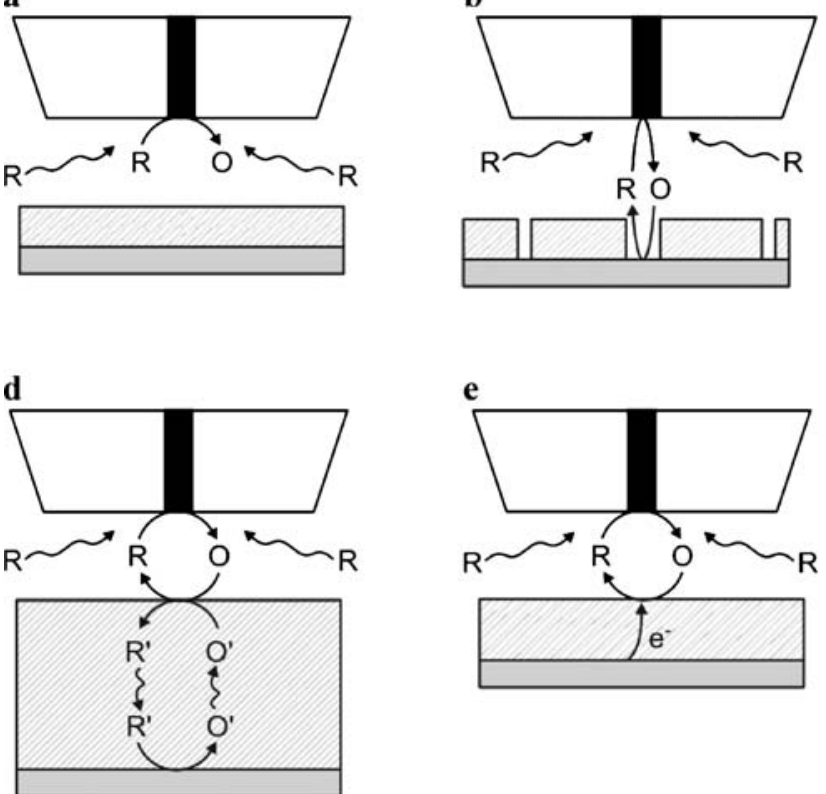

c

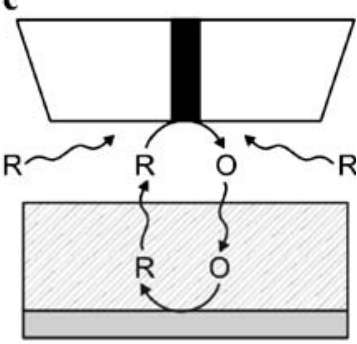

was possible by the determination of SECM approach curves [211-213]. A linear relationship is expected between normalized current and film thickness, assuming that the diffusion coefficients for the oxidized and reduced species are equivalent (Fig. 7b) [213]. Quantification of rates of

$\mathbf{a}$
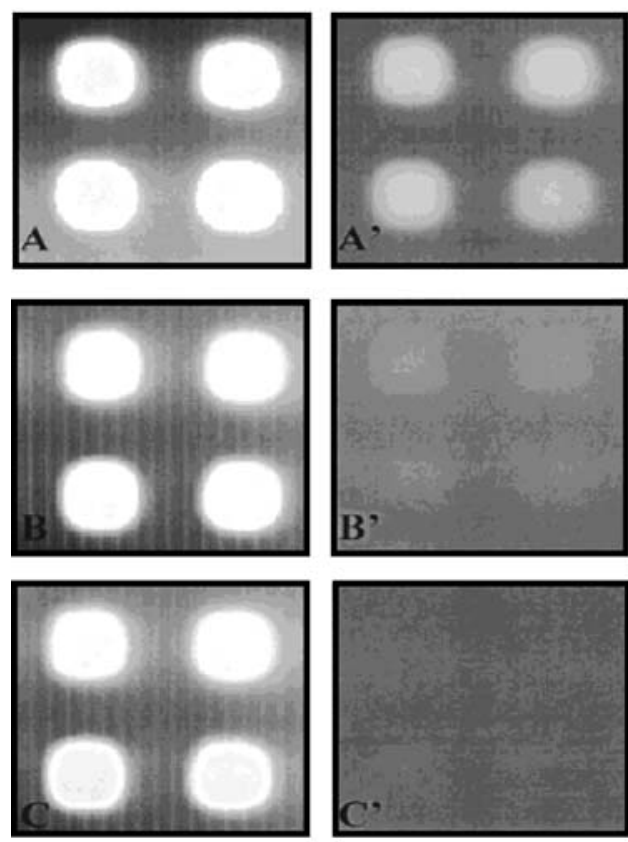

Fig. 7 (a) SECM images of a patterned array using a $4-\mu \mathrm{m}$ radius carbon fiber tip held at $0 \mathrm{~V}$ relative to $\mathrm{Ag} / \mathrm{AgCl}$ scanning at a rate of $30 \mathrm{~mm} \mathrm{~s}^{-1}\left(\mathbf{A}, \mathbf{A}^{\prime}\right) 4.8 \mathrm{mmol} \mathrm{L}^{-1} \mathrm{Ru}\left(\mathrm{NH}_{3}\right)_{6}^{3+}, \mathrm{E}_{\mathrm{S}}=-0.35 \mathrm{~V} ;\left(\mathbf{B}, \mathbf{B}^{\prime}\right)$ $5.1 \mathrm{mmol} \mathrm{L}^{-1}\left[\mathrm{Fe}(\text { phen })_{3}\right]\left(\mathrm{SO}_{4}\right), E_{\mathrm{S}}=+0.5 \mathrm{~V},\left(\mathbf{C}, \mathbf{C}^{\prime}\right) 4.3 \mathrm{mmol} \mathrm{L}{ }^{-1}$ $\mathrm{Na}_{4}\left[\mathrm{Fe}\left(\mathrm{bphen}\left(\mathrm{SO}_{3}\right)_{2}\right)_{3}\right], \mathrm{E}_{\mathrm{S}}=+1.0 \mathrm{~V}$. Images on the left are scans of bare ITO patterned substrate; images on the right are images taken at the same tip-substrate separation distance $(2 \mu \mathrm{m})$ but the substrate is a molecular transport through patterned poly $-\mathrm{Fe}\left(5-\mathrm{NH}_{2}-\right.$ phen $)_{3}^{2+}$ films supported on ITO substrates has been achieved by use of mediators of different sizes $\left(\left[\mathrm{Ru}\left(\mathrm{NH}_{3}\right)_{6}\right]^{3+}\right.$ $(0.55 \mathrm{~nm}),\left[\mathrm{Fe}(\text { phen })_{3}\right]^{2+}(1.3 \mathrm{~nm}), \mathrm{Fe}($ bathophenanthroline $)$ $(2.4 \mathrm{~nm}))$. For $12 \mathrm{~nm}$ thick poly $-\mathrm{Fe}\left(5-\mathrm{NH}_{2}-\text { phen }\right)_{3}^{2+}$

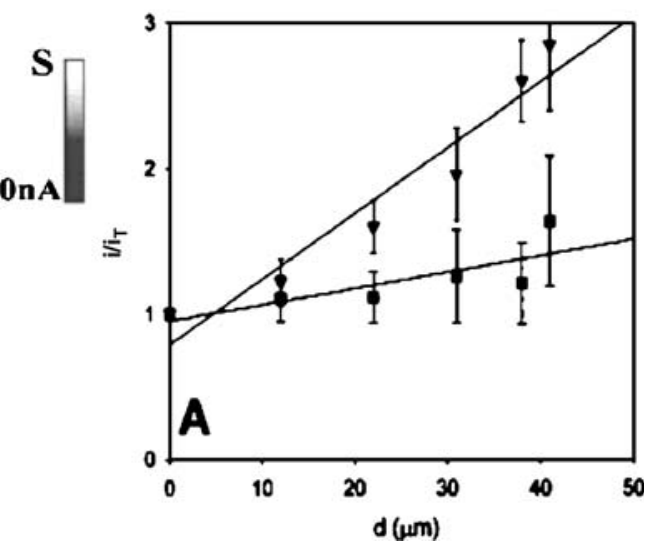

$12 \mathrm{~nm}$ thick film of electrodeposited polymer. (b) Plot of normalized tip current against polymer film thickness (d) for a photo resist/ITO patterned substrate of the redox mediators $\mathrm{Ru}\left(\mathrm{NH}_{3}\right)_{6}^{3+}$ (inverted triangles), and $\mathrm{FcMeOH}$ (squares) $\left(E_{\mathrm{S}}=-0.35\right.$ and $+0.35 \mathrm{~V}, E_{\mathrm{T}}=$ $0.0 \mathrm{~V}$ relative to $\mathrm{Ag} / \mathrm{AgCl}$ ). (Reprinted, with permission, from Ref. [213]. Copyright 2000, American Chemical Society) 
films no tip permeation current was observed for $[\mathrm{Fe}$ (phen $\left.)_{3}\right]^{2+}$ and $\mathrm{Fe}$ (bathophenanthroline) whereas the smaller $\left[\mathrm{Ru}\left(\mathrm{NH}_{3}\right)_{6}\right]^{3+}$ could penetrate the film (Fig. 7a). From linear regression of $i / i_{\mathrm{T}}$ a $P D_{\mathrm{F}}$ of $(10 \pm 2) \times 10^{9} \mathrm{~cm}^{2} \mathrm{~s}^{-1}$ was obtained for $\left[\mathrm{Ru}\left(\mathrm{NH}_{3}\right)_{6}\right]^{3+}$; this was in good agreement with permeation rates obtained in rotating-disk experiments [214].

Electron transfer can, in contrast, be localized at the polymer-solution interface, with the conducting polymer behaving as conducting electrode material. A catalytic electron-transfer reaction between the conducting polymer and the redox couple, i.e. a bimolecular reaction, can also be envisaged [215]. Kinetic measurements and determination of the rate-limiting processes at different locations, i.e. in the bulk polymer, at the electrode-polymer interface, or at the polymer-solution boundary are necessary to unravel such complex processes. The spatial location of reactions in polymer films has been identified by use of SECM approach curves. The current at the UME depends on diffusion between the UME and polymer surface, the electron-transfer rate at the polymer-solution interface, charge transfer in the polymer films, and the rate of electron transfer between polymer and metallic substrate. By variation of the film thickness, the electrode potential, and the distance between the UME and the polymer film, the rate of three of these processes can be varied over large ranges, enabling detailed analysis of the charge-transfer processes [209, 210, 215].

Electron transfer in redox systems dissolved in a polymer film has also been investigated [216, 217]. The redox system can be either dissolved in the film or covalently bound to the polymer chain. In the latter case, charge transport can occur only by electron hopping between neighboring redoxactive moieties [217].

SECM has also proved useful for measuring charge transport diffusion constants $\left(D_{\mathrm{CT}}\right)$ on the basis of transient SECM measurements [218]. If the UME is positioned close to the polymer-solution interface (in this case metallopolymers of the type Os(2,2' -bipyridyl $)_{2}$ (poly-4-vinylpyridine $)_{5}$ $\mathrm{Cl}] \mathrm{Cl}$ ) and used to generate a redox species in solution (here $\left.\left[\mathrm{Ru}(\mathrm{CN})_{6}\right]^{3-}\right)$ which diffuses to the polymer film where electron transfer occurs (Eq. 1), the $i-t$ transient in this step provides information about the kinetics of the electrontransfer (ET) process between the solution species and the polymer-bound moiety and about the concentration of redoxactive species in the polymer film.

$$
\mathrm{Os}_{\text {film }}^{\mathrm{II}}+\mathrm{Ru}(\mathrm{CN})_{6 \text { aq }}^{3-} \rightleftharpoons \mathrm{Os}_{\text {film }}^{\mathrm{III}}+\mathrm{Ru}(\mathrm{Cn})_{6 \text { aq }}^{4-}
$$

This process also creates lateral concentration gradients of $\mathrm{Os}^{\mathrm{II}}$ and $\mathrm{Os}{ }^{\mathrm{III}}$ along the film. If a waiting period is introduced after the first potential step in which $\left[\mathrm{Ru}(\mathrm{CN})_{6}\right]^{3-}$ is converted back to $\left[\mathrm{Ru}(\mathrm{CN})_{6}\right]^{4-}$ at the UME, Os ${ }^{\mathrm{II}}$ can recover in concentration by self-exchange between $\mathrm{Os}^{\mathrm{III}}$ and $\mathrm{Os}^{\mathrm{II}}$ moieties. If, thereafter, the potential of the UME is switched again to cause generation of the solution-phase oxidant $[\mathrm{Ru}$ $\left.(\mathrm{CN})_{6}\right]^{3-}$, the $i-t$ behavior associated with this step is affected significantly by the extent of the lateral electron hopping in the waiting period and $D_{\mathrm{CT}}$ can be determined from its dependence on the exchange rate constant $k_{\mathrm{ex}}$ :

$D_{\mathrm{CT}}=\lambda k_{\mathrm{ex}} \delta^{2} c_{\text {film }}$

where $c_{\text {film }}$ is the concentration of charge carriers, $\delta$ the intersite separation between redox centers, and $\lambda$ depends on the dimensionality of the system.

Although SECM was recently shown to enable measurement of the conductivity of ultra-thin films, by use of the feedback mode [219, 220], C-AFM measurements are probably easier to perform and are still preferred. Although there are reports of determination of the electronic state of conducting polymer films by use of both STM and Kelvin force microscopy [33, 221-223], STM is usually limited to very thin polymer films whereas Kelvin force microscopy can only be used for mapping the surface potential, and quantitative studies are difficult $[224,225]$. The advantage of C-AFM in this respect is that contact can be made directly between the conducting tip and the substrate by maintaining a prescribed load force [226, 227]. Current images can be obtained next to topographic images and the spatial doping distribution can be revealed [226]. More quantitative results are obtained by recording $I-V$ curves for selected areas by continuously measuring the current as a function of the potential bias which is linearly scanned from positive to negative potentials. The electrical characteristics of conducting and nonconducting regions can thus be established. $I-V$ curves for different areas of a partially doped polyaniline film prepared by in situ polymerization and deposition of aniline on ITO substrates are seen in Fig. 8. From the recorded $I-V$ curves the conductivity $\sigma$ of

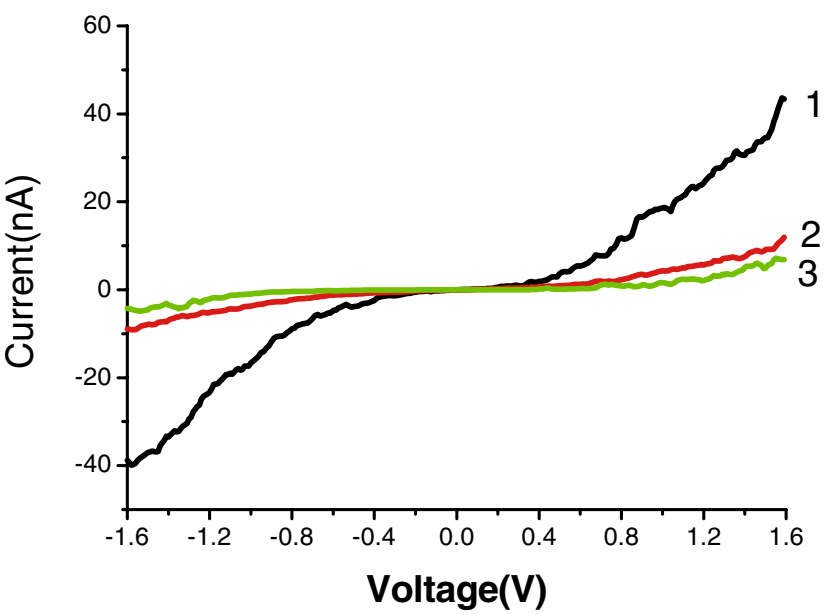

Fig. $8 I-V$ curves for a partially doped polyaniline film $200 \mathrm{~nm}$ thick deposited on ITO. (Reprinted in part, with permission, from Ref. [228]. Copyright 2005, American Chemical Society) 
different regions in the polymer film can be extracted by use of Eq. 3 [228]

$\sigma=\frac{d}{A R}$

where $d$ is the film thickness, $A$ the area of the C-AFM probe in contact with the surface (can be computed as $\pi r^{2}$ with the assumption that the contact radius between tip and sample is $50 \mathrm{~nm}$ ), and $R$ is the resistance of the sample, estimated from the inverse slope of the $I-V$ curve. If the $I-V$ curve was not linear the slope was estimated from the linear fit of the curve. The conductivity determined from the linear part of $I-V$ curves for this polymer film ranges from $5.3 \times 10^{-3}$ to $6.0 \times 10^{-4} \mathrm{~S} \mathrm{~cm}^{-1}$ [228].

Besides their use for surface analysis, SECM and CAFM have proved unique tools for forming polymer structures of well-defined shapes and dimensions. A variety of successful examples of localized polymerization of conducting polymers using SECM is described in the literature. The first report was on microdeposition of polyaniline on platinum electrodes in the direct mode [229] followed by deposition of polypyrrole on gold-coated glass with a lateral resolution of $60 \mu \mathrm{m}$ [230, 231]. The direct mode causes strong diffusional broadening, however, resulting in reduced lateral resolution. Deposition of polyaniline patterns on gold, platinum, and carbon surfaces using $\mathrm{pH}$ shifts induced by the feedback mode helped to overcome this problem [232]. Taking advantage of the insolubility of $2^{\prime}, 5^{\prime}$-bis(1-methylpyrrol-2-yl)thiophene in aqueous solutions, the synthesis of poly[2',5'-bis(1-methylpyrrol-2-yl)thiophene] on PMMA with lateral resolution as high as $15 \mu \mathrm{m}$ was also achievable [233]. Even smaller polythiophene patterns could be formed on oxidized manganese dioxide locally activated by tip-generated protons [234]. By addition of a proton scavenger the diffusion field of the proton was focused and $8 \mu \mathrm{m}$ resolution was achieved with a $10 \mu \mathrm{m}$ Pt electrode. By use of an electrochemical scanning near-field optical microscope, polypyrrole deposits were fabricated on boron-doped diamond electrodes [235]. Nanometer sized deposits can be achieved mainly by nanolithographic approaches. Next to surface probe microscopy techniques, for example dip-pen nanolithography (DPN), electrochemical DPN, electrostatic nanolithography, and electron beam lithography [236-239], nanolithography based on C-AFM has been extensively used for nanopatterning of monomer and precursor polymer films [240-244], in contrast with DPN and electrostatic nanolithography, in which monomer inks or electrolyte-saturated films are used [236, 237, 241]. C-AFM enables direct preparation of polymer films by electrochemical means on spin-cast monomers under ambient temperature and humidity conditions. One example is the local polymerization of carbazole films by electro-
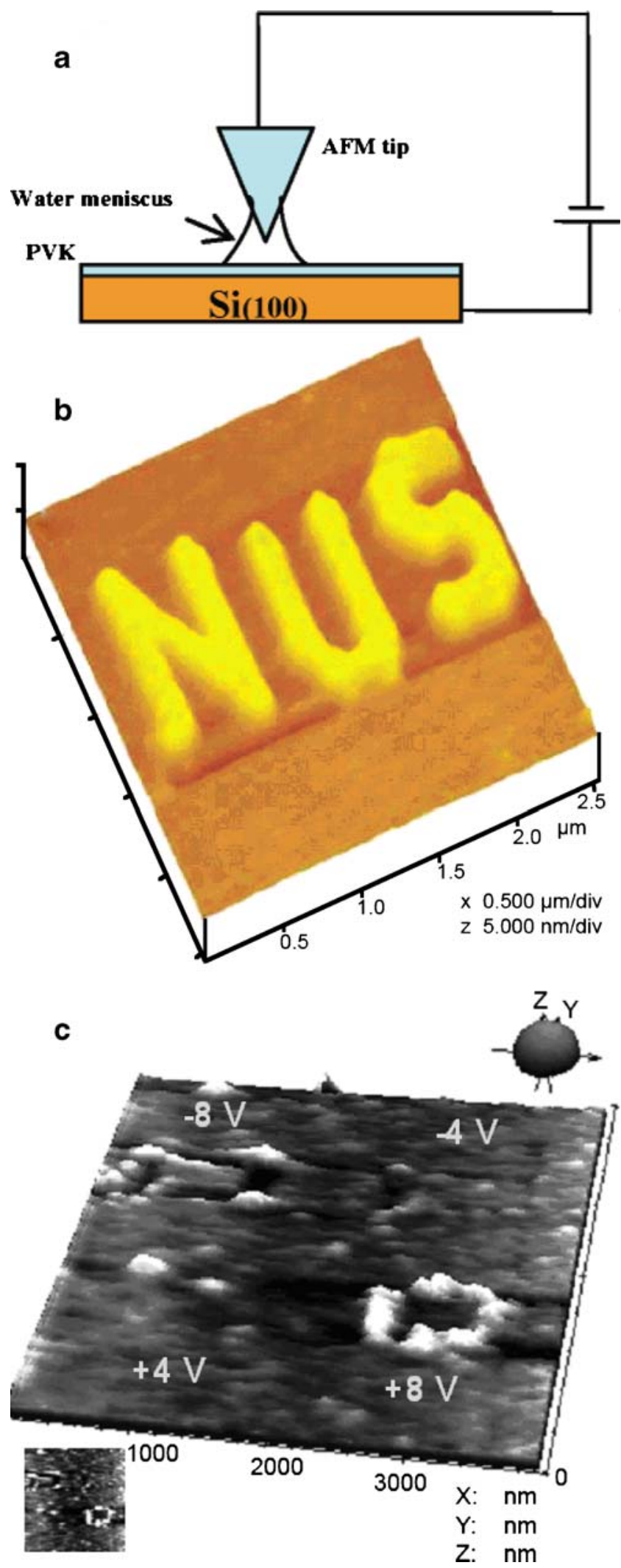
Fig. 9 (a) Schematic diagram of AFM nanolithography. (b) AFM image of a locally polymerized carbazole film spin-coated on a silicon substrate with a negatively biased AFM tip. (c) AFM height image of quinquenthiophene/phthalocyanine films (four bilayers) after writing at positive and negative bias. (Reproduction of $\mathrm{a}$ and $\mathrm{b}$ in part, with permission, from Ref. [242]. Copyright 2006, American Chemical Society. Reproduction of c in part, with permission, from Ref. [244]. Copyright 2006 American Chemical Society)

chemical polymerization of thin films using a voltagebiased AFM (Fig. 9a,b) [242]. The same approach led to polyvinylcarbazole films on Si substrates. The conductivity of the pattern could be derived from $I-V$ curves and was estimated to be $1.5 \times 10^{-3} \mathrm{~S} \mathrm{~cm}^{-1}$ for polyvinylcarbazole films on Si. Nanopatterning and nanocharge in ultra-thin films of quinquethiophene/phthalocyanine using C-AFM formed a novel write/read memory device [244]. AFM height images had dented and raised morphological features that could be electrically manipulated by changing the direction of the bias voltage (Fig. 9c).

\section{Self assembled monolayers}

The modification of electrode surfaces by a layer of aligned molecules is of great scientific importance because of the potential applications of such systems as barrier films for corrosion protection, for chemical and biological sensing, or as lithographic resists. Perhaps the most widely studied molecular layers are self assembled monolayers (SAMs). SAMs are highly ordered molecular assemblies formed by the adsorption of an active surfactant on a solid surface $[245,246]$. The most common SAMs are $n$-alkanethiols adsorbed on gold by $\mathrm{Au}-\mathrm{S}$ linkage and functionalized silanes covalently linked to oxide films by $\mathrm{O}-\mathrm{Si}$ linkage. Understanding and controlling long-range electron transfer across such molecular assemblies nanometers thick is particularly important to technological systems such as molecular electronics and sensor designs. Many techniques have been used to investigate the structure of a monolayer of alkanethiol on a gold substrate. By use of in-situ AFM it is possible to follow the adsorption process in real time, revealing information about the kinetics and mechanism of the process to be elucidated [247]. STM measurements reveal details about the packing of thiol molecules at a subnanometer level [248-250]. It is now well established that the complete monolayers formed on $\mathrm{Au}(111)$ adopt a commensurate $(\sqrt{3} \times \sqrt{3}) \mathrm{R} 30^{\circ}$ structure, which is further structured by a $\mathrm{c}(4 \times 2)$ superlattice. The superstructure is characterized by systematic arrangement of molecules with distinct height differences in STM images [250, 251]. The alkane chain is tilted at $30^{\circ}$ to the surface normal. SECM has also been used to study the structure of alkane thiols, because SECM signals respond very sensitively to defects in the monolayer. A defect-free monolayer passivates the gold substrate so strongly that it behaves like an insulator in SECM. No passivation occurs at defects, and high currents result. In contrast with transient techniques, for example cyclic voltammetry $(\mathrm{CV})$ and chronoamperometry (CA), which are widely used to estimate average defect size, coverage, and kinetics of ET across SAMs [252-255], the application of extreme potentials at which SAMs may be modified can be avoided in SECM investigations [256]. By subsequent application of different potentials to the sample, potential-dependent properties can be studied. The presence of resistive potential drop and the double layer charging current in $\mathrm{CV}$ and $\mathrm{CA}$ can also affect the reliability of the values measured; this has been tackled by SECM [253]. The formation of the SAM was followed by approach curves over time and the evaluation was based on a model of a partially covered electrode in which the uncovered areas are smaller than the UME [257]. By analogy with conducting polymers, several processes are involved in ET across a SAM [258]. The SAM simply acts as a blocking electrode. In this case, ET occurs by direct electron tunneling between the tip-produced electroactive species and the electrode or though pinholes in the film. The monolayer
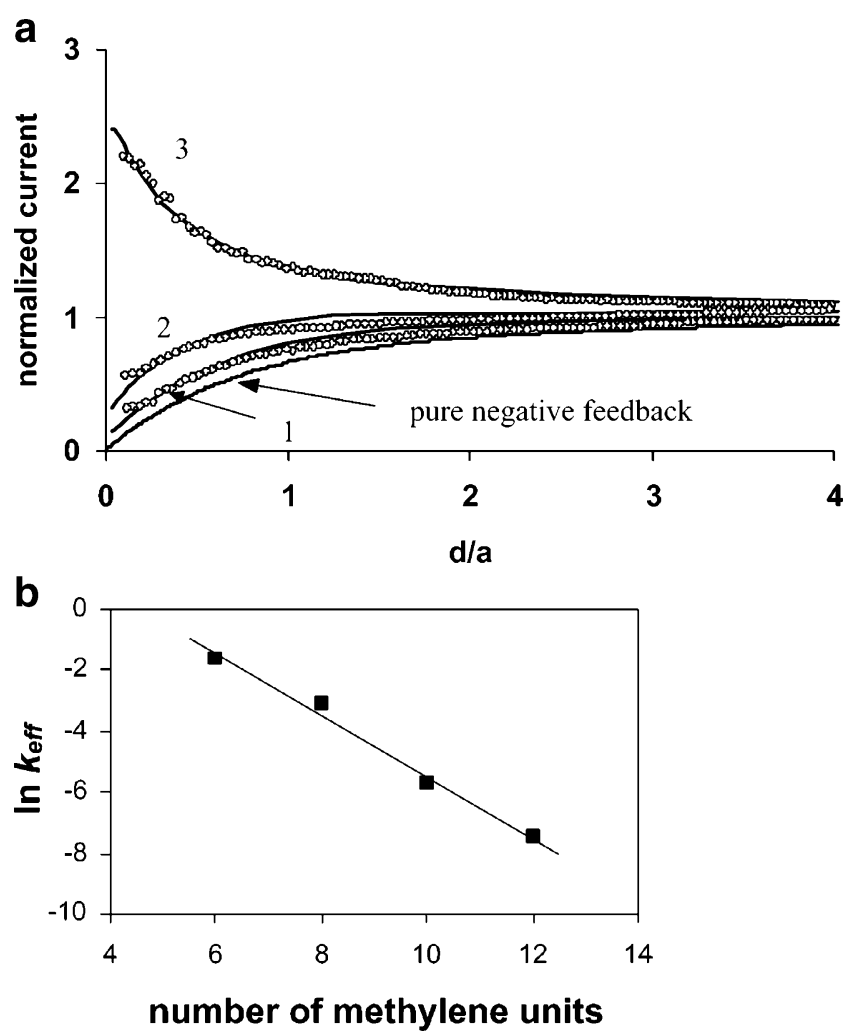

Fig. 10 (a) SECM approach curves obtained on gold coated with a mixed monolayer of ferroceneCONH$\left(\mathrm{CH}_{2}\right)_{7} \mathrm{SH}$ and $\mathrm{CH}_{3}\left(\mathrm{CH}_{2}\right)_{8} \mathrm{SH}$ in a solution containing $1 \mathrm{mmol} \mathrm{L}{ }^{-1} \mathrm{Ru}\left(\mathrm{NH}_{3}\right)_{6}^{3+}, \mathrm{E}_{\mathrm{S}}=(1) 0.2,(2,3)$ $0.5 \mathrm{~V}$ relative to $\mathrm{Ag} / \mathrm{AgCl}$; curve 2 was obtained on a $\mathrm{CH}_{3}\left(\mathrm{CH}_{2}\right)_{8} \mathrm{SH}$ monolayer only. (b) dependence of $\ln \mathrm{k}_{\mathrm{eff}}$ on the number of methylene units in alkanethiols. (Reprinted, with permission, from Ref. [258]. Copyright 2004, American Chemical Society) 
may contain redox centers and ET occurs via a bimolecular reaction between the dissolved redox species generated at the $\mathrm{UME}$ and the redox centers attached to the SAM, followed by electron tunneling. By use of SECM approach curves, rate constants of all these processes and the combination of different components could be determined. To illustrate this, ET has been examined on ferrocene-terminated long-chain monolayers on gold (Fig. 10a,b) [258] and a similar approach has been used to measure ET of thiol-porphyrin monolayers on gold before and after addition of metal ions [259]. Depending on the potential applied to the electrode, the feedback current can be attributed to direct electron tunneling or ET through pinholes. SECM approach curves with use of different redox mediators show that the insulating properties increase with increasing chain length of the SAM-forming molecule [260]. By use of nanometersized electrodes it was shown that direct electron transfer through the layer, rather than electron transfer at the defects, was dominant and that the size of the defects was 1-100 nm [261]. Indeed, the present consensus is that SAMs are collectively organized in different phases constrained by disordered boundaries and substrate defects [251]. The approach of Abbou et al. [74] is also notableby use of the combined AFM-SECM technique they probed the structure and dynamics of polymer chains labeled on one end with a ferrocene unit and grafted on the other end to a gold surface.

Because of the almost unlimited possibilities of introducing functional groups in SAMs of alkanethiols, they are suitable models and attractive molecules for molecular electronics, in which formation of metal/molecule/metal junctions is of central importance. The construction of molecular devices comprises two steps-synthesis of conjugated molecular wires [262, 263] and assembly of the metal $/$ molecule/metal junction, which can be based on nanofabricated electrodes [264], crossed wires [265], and self-assembly of appropriately substituted molecules on metals in a monolayer $[245,266]$. Probably the most critical property for a functioning junction is the conductivity of the assembly. By conductance measurements the effect of structure and electronic properties on the charge-transport characteristics of the molecular bridge can be determined. STM and C-AFM, in conjunction with methods including use of Hg-drop electrodes, have been used as promising tools for studying the electrical conductance of molecules along the molecular axis [267, 268], crossed wires [269], and break junctions $[270,271]$. As early as the late 90 s, the conductance of single molecules embedded in insulating SAM films was discussed and evaluated by Bumm et al. [237] and others [272-276], by use of STM. It was, however, shown that estimation of the electrical conductance of adsorbed molecules by use of STM is quite complicated compared with techniques in which the electrode is directly attached to the molecules [267-271]. C-AFM has been found to be a good candidate for direct measurement of electrical conduction by organic monolayers such as SAMs $[25,277-288]$. The advantages of C-AFM over STM are that the electronic properties of a molecular function are sensitive to the effects of deformation caused by the force of interaction between the tip and the sample [25, 285, 287]. The simultaneous measurement of force and current to properly characterize charge transfer through molecular junctions is important. It can be achieved directly by use of C-AFM, whereas the contact force is neither known nor controlled in STM. A key advantage of C-AFM for junction fabrication is that no microfabrication or nanofabrication processes are necessary. This means that in terms of time, screening of junction behavior is limited by the synthesis of molecules and their assembly on conducting substrates and not by the method used for measurement. A junction can be fabricated by placing a conducting AFM tip in contact with a metal-supported molecular film (Fig. 11). The normal force
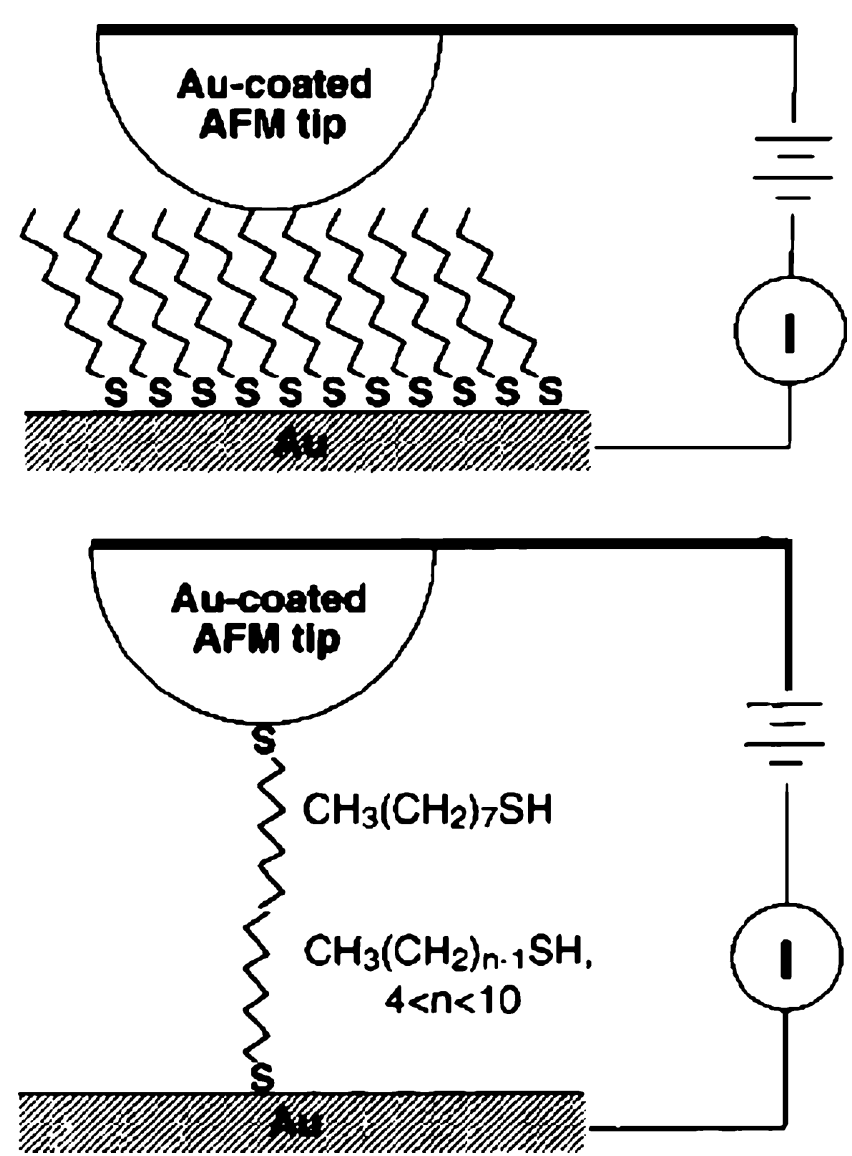

Fig. 11 Formation of monolayer and bilayer junction using a goldcoated AFM tip. For the bilayer junction the tip was coated with a $\mathrm{CH}_{3}\left(\mathrm{CH}_{2}\right)_{7} \mathrm{SH} \mathrm{SAM}$, voltages were applied to the probe tips, and the substrate was grounded. (Reprinted, with permission, from Ref. [25]. Copyright 2001, American Chemical Society) 

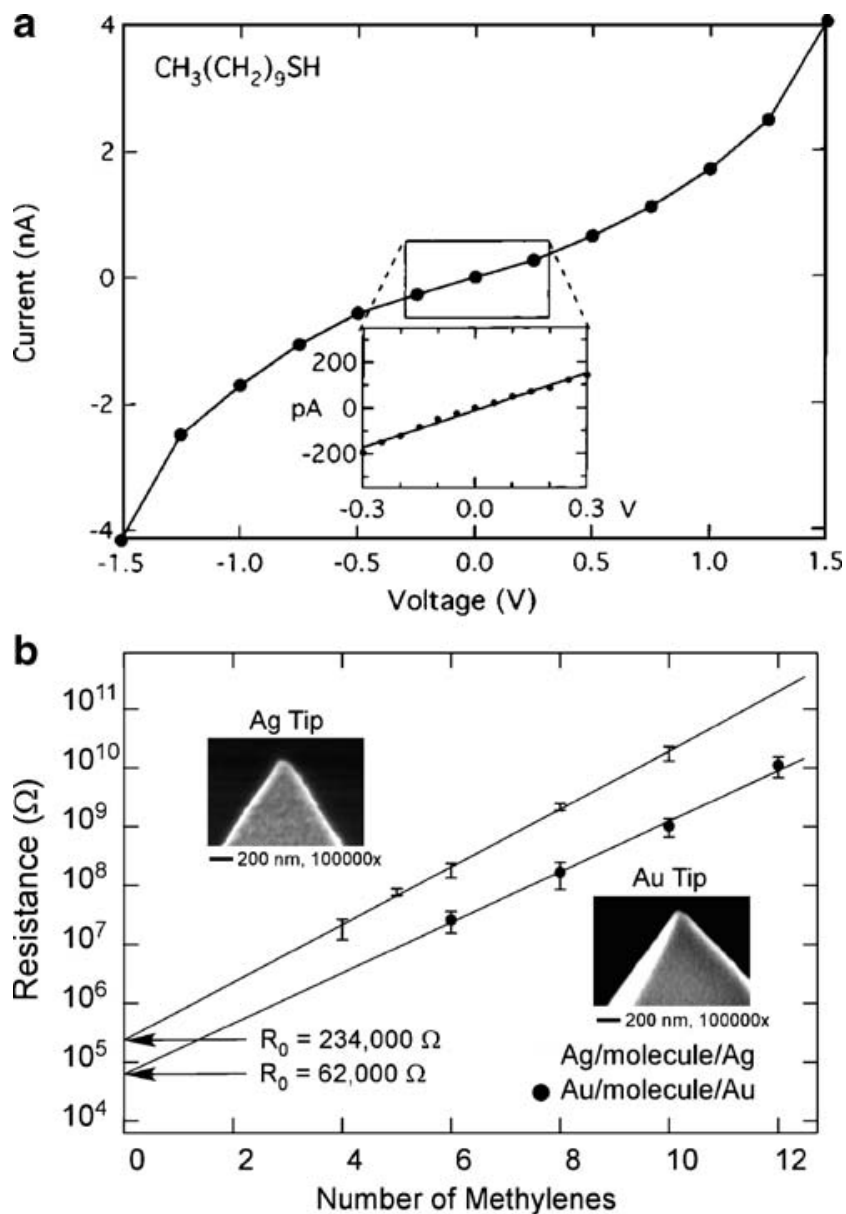

Fig. 12 (a) $I-V$ characteristics of a $\mathrm{CH}_{3}\left(\mathrm{CH}_{2}\right)_{9} \mathrm{SH}$ monolayer junction. (b) Relationship between junction resistance and chain length for alkanethiol junctions with $\mathrm{Ag}$ and $\mathrm{Au}$ contacts. Inset shows SEM image of tip. (Reproduction of a, with permission, from Ref. [25]. Copyright 2001, American Chemical Society. Reproduction of b, in part, with permission, from Ref. [280]. Copyright 2002, American Chemical Society) feedback circuit of the AFM controls the mechanical load on the microcontact while the $I-V$ characteristics are recorded. The ability to manipulate the load on the microcontact is a remarkable benefit, because it provides the opportunity to probe the relationship between mechanical deformation of molecules and their transport properties. Additionally, the load-dependent tip/SAM contact area in this junction is small $\left(10 \mathrm{~nm}^{2}\right)$ meaning the junction reflects transport through a small number of molecules, typically fewer than 100 for a probe of $50 \mathrm{~nm}$ radius. Transport through metal/molecule/metal junctions depends critically on the properties of the contact. The resistance $R$ for a junction is expressed as

$R=R_{0} \exp (\beta s)$

where $R_{0}$ is the contact resistance, $s$ the junction length, and the exponential prefactor $\beta$, with units of $1 /$ length, is a structure-dependent measure of transport efficiency. To obtain correct resistance values, the voltage drop at the contacts must be accounted for [280, 289]. The resistance of the molecular bridge can be obtained without knowing $R_{0}$ by measuring the junction resistance as a function of electrode spacing, yielding the resistance per unit length of the molecules, a quantity that is independent of the properties of the contact [25]. A typical $I-V$ curve for a gold-coated AFM tip in contact with an SAM of decanethiol on gold is shown in Fig. 12a. The trace is sigmoidal over the $\pm 1.5 \mathrm{~V}$ sweep, but is linear inside $\pm 0.3 \mathrm{~V}$ from where the junction resistance is determined. The resistance increases exponentially with the number of carbon atoms in the chain, as expected for nonresonant electron tunneling. A value of $\beta=1.15 /$ carbon is obtained from the slope (Fig. 12b). Voltage excursion beyond $1.5 \mathrm{~V}$ results in junction breakdown, which is also chain-length dependent. The current debate is whether the transport mechanism is
Fig. 13 KFM images $(10 \times$ $10 \mu^{2}$ ) of (a) ODS/FAS SAM and (b) ODS/AHAPS SAM. (From Chem Phys Lett, 349, Saito N, Hayashi K, Sugimura H, Takai O, Nakagiri N, Surface potentials of patterned organosilane self-assembled monolayers acquired by Kelvin probe force microscopy and ab initio molecular calculation, pp 172177 , Copyright 2001, with permission from Elsevier) $\mathbf{a}$

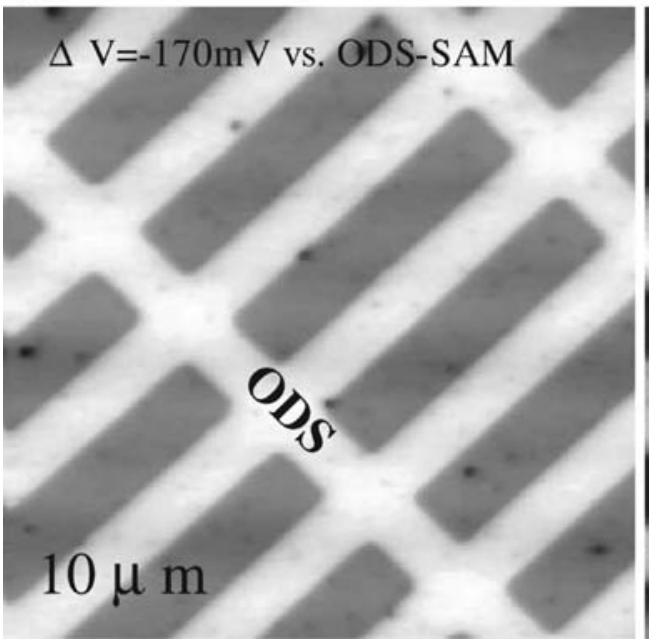

b

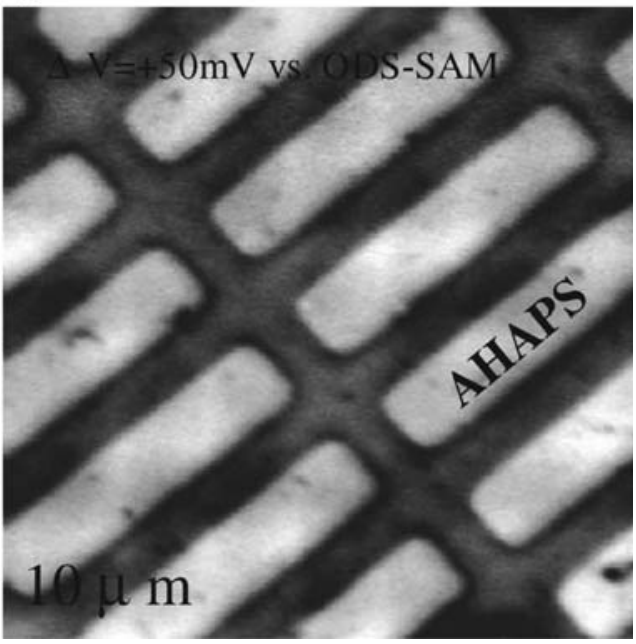


through-bond or through-space tunneling. Work on rigid thiol-terminated norbornane SAMs supports the theory of through-bond tunneling [281].

When imaging molecular adsorbates using AFM, care must be taken to apply a minimum tip-substrate loading force to avoid unwanted effects, for example displacement of molecules from the surface or cleaning of the surface. This is commonly used in AFM as a method for estimating the thickness of a molecular film and for surface microlithography [290, 291]. The review by Kraemer et al. [291] is an endless resource of work done in this field. Briefly, the manipulation of individual alkanethiolate and functionalized silane molecules by STM, C-AFM, and SECM [71, 292-297] is mainly based on regeneration of a gold surface either by electrochemically initiated removal of the chemisorbed thiolate from the gold surface (Eq. 5) or by oxidative decomposition (Eq. 6).

$$
\begin{aligned}
& \mathrm{AuSR}+\mathrm{e} \rightarrow \mathrm{Au}^{0}+\mathrm{RS}^{-} \\
& \mathrm{AuSR}+2 \mathrm{H}_{2} \mathrm{O} \rightarrow \mathrm{Au}^{0}+\mathrm{RSO}_{2}^{-}+3 \mathrm{e}+4 \mathrm{H}^{+}(\mathrm{pH}>7)
\end{aligned}
$$

Next to feedback mode-based SECM [298], KFM is very useful for imaging the result of the patterning process, because in parallel to imaging it can be used to determine the electrical properties of the modified interface. It is based on determination of the surface potential of SAM-modified surfaces arising from the asymmetric electrical field that exists at the interface between two phases. The net surface potential of an alkanethiolate SAM comprises contributions from the dipole moments of the $\mathrm{Au}-\mathrm{S}$ bonds and the alkane chains [299]. The net dipole moment of an unsubstituted alkanethiolate layer, for example, is directed toward the sulfur atoms, because they draw electron density from the gold surface. Fluorinating the chains will strongly shift the net dipole moment in the opposite direction [300]. The surface potential $E_{\text {surf }}$ of a polar SAM can be represented by the equation [245]:

$E_{\text {surf }}=\frac{\sigma d}{\varepsilon_{r} \varepsilon_{0}}$

where $\sigma$ is the surface charge density, $d$ the thickness of the monolayer, $\varepsilon_{\mathrm{r}}$ the relative dielectric constant of the monolayer, and $\varepsilon_{0}$ the permittivity of free space. On substitution of the hydrogen atoms of the alkanethiol by fluorine the induced charge asymmetry can be obtained by measuring $E_{\text {surf }}$ [301]. This difference between $E_{\text {surf }}$ values can be used for imaging of mixed [302] or micropatterned $[303,304]$ SAMs. Figure 13 shows KFM images of an $n$ octadecyltrimethoxysilane (ODS) and heptadecafluoro1,1,2,2-tetrahydrodecyl-1-trimethoxysilane (FAS) patterned silicon substrate, and of an ODS/AHAPS ( $n$-(6-aminohexyl) aminopropyltrimethoxysilane) SAM.

\section{Conclusions}

The development of electrochemical and electrical scanning probe techniques during the past two decades has led to new possibilities of local study of interfacial phenomena on solid surfaces such as metals, insulators, and semiconductors. These surfaces include polymers and thin films formed by self-assembly and different polymerization techniques (chemical, optical, electrochemical) down to the atomic level. The broad effect of these new techniques on materials science, surface chemistry and physics, sensorics, and medicine, and on nano-electronics is widely accepted. SPM techniques are routinely used to characterize the structural and thermodynamic properties of solid-state surfaces. It is indisputable that these techniques have become standard tools in materials science for investigation of local surface reactions leading to a better understanding of surface processes. Investigation of solid/liquid interfaces can be performed under electrochemical conditions, and under such conditions electrochemistry has a great advantage compared with local probe studies under UHV or gas environmental conditions, because the Fermi levels of both the substrate and conducting probing tip can be adjusted precisely and independently of each other. By use of SPM techniques a clearer and more precise understanding of fundamental concepts, for example mass and charge transfer through thin and porous films (polymers, SAMs, oxide films) and the effect of structure and electronic properties on the chargetransport characteristics of molecular bridges in metal/ molecule/metal junctions, has been obtained. Comparison of results obtained by local probe techniques with those obtained by integral techniques has shown the relevance of obtaining spatially resolved information about physical properties such as local conductivity and corrosion resistance. Having overcome many experimental limitations, the future of SPM methods in materials science will be guided by its use for investigation of complex processes and interfaces. They will help with obtaining a better understanding of the microscopic and atomic structure of functional materials and will form a bridge between chemistry and electronics.

Acknowledgements SS thanks the Hanse Institute for Advanced Study for a three-month fellowship. GW acknowledges ongoing support by the Deutsche Forschungsgemeinschaft (Wi 1617/8) and the Fonds of Chemical Industries. The authors are thankful to R Advincula, A J Bard, J Beebe, H N McMurray, and C-G Wu for supplying the original figures in this review.

\section{References}

1. Heath JP (2005) Dictionary of microscopy. Wiley, Chichester

2. Binnig G, Rohrer H (1982) Helv Phys Acta 55:726

3. Nichols RJ, Magnussen OM, Hotlos J, Twomey T, Behm RJ, Kolb DM (1990) J Electroanal Chem 290:21 
4. Gewirth AA, Niece BK (1997) Chem Rev 97:1129

5. Sonnenfeld R, Hansma PK (1986) Science 232:211

6. Liu H-Y, Fan F-RF, Lin CW, Bard AJ (1986) J Am Chem Soc 108:3838

7. Lauritsen JV, Vang RT, Besenbacher F (2007) Applications of scanning electrochemical microscopy (SECM). In: Bhushan B, Fuchs H (eds) Applied scanning probe methods VII. Springer, Berlin Heidelberg New York, p 197

8. Budevski E, Staikov G, Lorenz WJ (eds) (1996) Electrochemical phase formation and growth. Wiley-VCH, Weinheim

9. Bard AJ, Fan F-RF (2001) Applications in electrochemistry. In: Bonnell D (ed) Scanning probe microscopy and spectroscopy. Wiley-VCH, New York, p 421

10. Maurice V, Marcus P (2006) Scanning tunneling microscopy and atomic force microscopy. In: Mansfeld F, Marcus P (eds) Analytical methods in corrosion science and engineering. CRC Press, Boca Raton, p 133

11. Höpfner M, Obretenov W, Jüttner K, Lorenz WJ, Staikov G, Bostanov V, Budevski E (1991) Surf Sci 248:225

12. Siegenthaler H (1992) STM in electrochemistry. In: Wiesendanger R, Güntherodt H-J (eds) Scanning tunneling microscopy II. Springer, Berlin Heidelberg New York, p 7

13. Gewirth AA, Siegenthaler H (eds) (1995) Nanoscale probes of the solid/liquid interface. Springer, Berlin Heidelberg New York

14. Itaya K (1998) Prog Surf Sci 58:121

15. Kolb DM, Schneeweiss MA (1999) Electrochem Soc Interface 26

16. Kolb DM (2001) Angew Chem Int Ed 40:1162

17. Boneberg J, Bohmisch M, Ochmann M, Leiderer P (1997) Appl Phys Lett 71:3805

18. Salmeron M, Xu L, Hu J, Dai Q (1997) MRS Bull 22:36

19. Wang X-D, Kulik J, Edwards NV, Samavedam SB, Lu S (2003) Mater Res Soc Symp Proc 738:183

20. Alamarguy D, Schneegans O, Noel S, Boyer L (2004) Appl Surf Sci 225:309

21. Fink N, Wilson B, Grundmeier G (2006) Electrochim Acta 51:2956

22. Liau Y-H, Scherer NF, Rhodes F (2001) J Phys Chem B 105:3282

23. Planès J, Houzé F, Chrétien P, Schneegans O (2001) Appl Phys Lett 79:2993

24. Cui XD, Primak A, Zarate X, Tomfohr J, Sankey OF, Moore AL, Moore TA, Gust DGH, Lindsay SM (2001) Science 294:571

25. Wold DJ, Frisbie CD (2001) J Am Chem Soc 123:5549

26. Dai H, Wong EW, Lieber CM (1996) Science 272:523

27. Nguyen TV, Nguyen MV, Lin G, Rao N, Xie X, Zhu D-M (2006) Electrochem Solid-State Lett 9:A88

28. Tseng RJ, Tsai C, Ma L, Ouyang J, Ozkan CS, Yang Y (2006) Nat Nanotechnol 1:72

29. Cheran L-E, Sadeghi S, Thompson M (2005) Analyst (Cambridge, U. K.) 130:1569

30. Baikie ID, Smith PJS, Porterfield DM, Estrup PJ (1999) Rev Sci Instrum 70:1842

31. Knapp HF, Mesquida P, Stemmer A (2002) Surf Interface Anal $33: 108$

32. Hansen DC, Hansen KM, Ferrell TL, Thundat T (2003) Langmuir 19:7514

33. Barisci JN, Stella R, Spinks GM, Wallace CG (2000) Electrochim Acta 46:519

34. Grundmeier G, Stratmann M (2005) Annu Rev Mater Res 35:571

35. Wapner K, Stratmann M, Grundmeier G (2006) Electrochim Acta 51:3303

36. Stratmann M, Feser R, Leng A (1994) Farbe + Lack 100:93

37. McMurray HN, Worsley DA (1997) Res Chem Kin 4:149

38. Schmitt G (1997) Mater Corros 48:586

39. Davenport AJ (1998) Electrochem Soc Interface 7:28
40. Grundmeier G, Schmidt W, Stratmann M (2000) Electrochim Acta $45: 2515$

41. Rohwerder M, Stratmann M (2000) Proc Electrochem Soc 9928:302

42. Neufeld A (2002) Materials World 10:33

43. Stratmann M (2005) Corrosion (Houston, TX, U. S.) 61:1115

44. Bard AJ, Fan F-RF, Pierce DT, Unwin PR, Wipf DO, Zhou FM (1991) Science 254:68

45. Bard AJ, Mirkin MV (eds) (2001) Scanning electrochemical microscopy. Marcel Dekker, New York

46. Engstrom RC, Weber M, Wunder DJ, Burgess R, Winquist S (1986) Anal Chem 58:844

47. Bard AJ, Fan F-RF, Kwak J, Lev O (1989) Anal Chem 61:132

48. Engstrom RC, Pharr CM (1989) Anal Chem 61:1099A

49. Bard AJ, Denuault G, Lee C, Mandler D, Wipf DO (1990) Acc Chem Res 23:357

50. Mandler D, Meltzer S, Shohat I (1996) Isr J Chem 36:73

51. Mirkin MV (1996) Anal Chem 68:177A

52. Bard AJ, Cliffel DE, Demaille C, Fan F-RF, Tsionsky M (1997) Ann Chim 87:15

53. Barker AL, Gonsalves M, Macpherson JV, Slevin CJ, Unwin PR (1999) Anal Chim Acta 385:223

54. Nagy G, Nagy L (2000) Fresenius J Anal Chem 366:735

55. Gyurcsanyi RE, Jagerszki G, Kiss G, Toth K (2004) Bioelectrochemistry 63:207

56. Amemiya S, Guo J, Xiong H, Gross DA (2006) Anal Bioanal Chem 386:458

57. Sun P, Laforge FO, Mirkin MV (2007) Phys Chem Chem Phys 9:802

58. Wittstock G, Burchardt M, Pust SE, Shen Y, Zhao C (2007) Angew Chem Int Ed 46:1584

59. Bard AJ, Faulkner LP (2001) Electrochemical methods: fundamentals and applications. Wiley, New York

60. Bard AJ, Fan F-RF, Mirkin MV (1994) Scanning electrochemical microscopy. In: Bard AJ (ed) Electroanalytical chemistry. Marcel Dekker, New York, p 244

61. Bard AJ, Fan F-RF, Mirkin MV (1995) Scanning electrochemical microscopy. In: Rubinstein J (ed) Physical electrochemistry: principles, methods and applications. Marcel Dekker, New York, p 209

62. Mandler D (2001) Micro- and nanopatterning using the scanning electrochemical microscopy. In: Bard AJ, Mirkin MV (eds) Scanning electrochemical microscopy. Marcel Dekker, New York, p 593

63. Shiku H, Ohya H, Matsue T (2002) Scanning electrochemical microscopy applied to biological systems. In: Bard AJ, Stratmann M (eds) Encyclopedia of electrochemistry. Wiley, Weinheim, p 257

64. Barker AL, Gardner CE, Macpherson JV, Unwin PR, Zhang J (2003) Characterization of biomolecular interfaces with scanning electrochemical microscopy: from model monolayers to tissues and cells. In: Rusling JF (ed) Surfactant Science Series, Biomolecular films, design, function and applications. Marcel Dekker, New York, p 253

65. Horrocks BR (2003) Scanning electrochemical microscopy. In: Bard AJ, Stratmann M (eds) Encyclopedia of electrochemistry. Wiley-VCH, Weinheim, p 444

66. Wittstock G (2003) Imaging localized reactivities of surfaces by scanning electrochemical microscopy. In: Wandelt K, Thurgate S (eds) Solid-liquid interfaces, macroscopic phenomena-microscopic understanding. Springer, Berlin Heidelberg New York, p 335

67. Wittstock G, Burchardt M, Pust SE (2007) Applications of scanning electrochemical microscopy (SECM). In: Bhushan B, Fuchs H (eds) Applied scanning probe methods VII. Springer, Berlin Heidelberg New York, p 259 
68. Williams DE, Mohiuddin TF, Zhu YY (1998) J Electrochem Soc 145:2664

69. Kucernak AR, Chowdhury PB, Wilde CP, Kelsall GH, Zhu YY, Williams DE (2000) Electrochim Acta 45:4483

70. Treutler TH, Wittstock G (2003) Electrochim Acta 48:2923

71. Sklyar O, Treutler TH, Vlachopoulos N, Wittstock G (2005) Surf Sci 597:181

72. Macpherson JV, Unwin PR (2000) Anal Chem 72:276

73. Kranz C, Friedbacher G, Mizaikoff B, Lugstein A, Smoliner J, Bertagnolli E (2001) Anal Chem 73:2491

74. Abbou J, Anne A, Demaille C (2004) J Am Chem Soc 126:10095

75. Fasching RJ, Tao Y, Prinz FB (2004) Chem Sens 20:318

76. Davoodi A, Pan J, Leygraf C, Norgren S (2005) Electrochem Solid-State Lett 8:B21

77. Gullo MR, Frederix PLTM, Akiyama T, Engel A, de Rooij NF, Staufer U (2006) Anal Chem 78:5436

78. Ballesteros Katemann B, Schulte A, Schuhmann W (2003) Chem Eur J 9:2025

79. Ballesteros Katemann B, Schulte A, Schuhmann W (2004) Electroanalysis 16:60

80. Pust SE, Scharnweber D, Nunes Kirchner C, Wittstock G (2007) Adv Mater 19:878

81. Tanabe H, Yamamura Y, Misawa T (1995) Mater Sci Forum 185-188:991

82. Zhu Y, Williams DE (1997) J Electrochem Soc 144:43

83. Lister TE, Pinhero PJ (2003) Electrochim Acta 48:2371

84. Lister TE, Pinhero PJ (2003) Proc Electrochem Soc 2002-24:368

85. Luong BT, Nishikata A, Tsuru T (2003) Electrochemistry (Tokyo, Jpn.) 71:555

86. Casillas N, Charlebois SJ, Smyrl WH, White HS (1993) J Electrochem Soc 140:142

87. Casillas N, Charlebois SJ, Smyrl WH, White HS (1994) J Electrochem Soc 141:636

88. Basame SB, White HS (1995) J Phys Chem 99:16430

89. Basame SB, White HS (1998) J Phys Chem B 102:9812

90. Garfias-Mesias LF, Alodan M, James P, Smyrl WH (1998) J Electrochem Soc 145:2005

91. Basame SB, White HS (1999) Anal Chem 71:3166

92. Basame SB, White HS (1999) Langmuir 15:819

93. Paik CH, Alkire RC (2001) J Electrochem Soc 148:B276

94. Serebrennikova I, White HS (2001) Electrochem Solid-State Lett 4: B4

95. Serebrennikova I, Lee S, White HS (2002) Faraday Discuss 121:199

96. Paik C-H, White HS, Alkire RC (2000) J Electrochem Soc 147:4120

97. Lister TE, Pinhero PJ (2005) Anal Chem 77:2601

98. Wipf DO (1994) Colloid Surf A 93:251

99. Still JW, Wipf DO (1997) J Electrochem Soc 144:2657

100. Tanabe H, Togashi K, Misawa T, Mudali UK (1998) J Mater Sci Lett 17:551

101. Fushimi K, Seo M (2001) Electrochim Acta 47:121

102. Völker E, Inchauspe CG, Calvo EJ (2006) Electrochem Commun 8:179

103. Gilbert JL, Smith SM, Lautenschlager EP (1993) J Biomed Mater Res 27:1357

104. Gilbert JL, Zarka L, Chang E, Thomas CH (1998) J Biomed Mater Res 42:321

105. Shreve GA, Karp CD, Pomykal KE, Lewis NS (1995) J Phys Chem 99:5575

106. Fushimi K, Okawa T, Azumi K, Seo M (2000) J Electrochem Soc 147:524

107. Fushimi K, Okawa T, Seo M (2000) Electrochemistry (Tokyo, Jpn.) 68:950

108. Park JO, Paik C-H, Alkire RC (1996) J Electrochem Soc 143: L174

109. Seegmiller JC, Buttry DA (2003) J Electrochem Soc 150:B413
110. Belger S, Schulte A, Hessing C, Pohl M, Schuhmann W (2004) Materialwiss Werkstofftech 35:276

111. Schulte A, Belger S, Etienne M, Schuhmann W (2004) Mater Sci Eng A 378:523

112. Lister TE, Pinhero PJ, Trowbridge TL, Mizia RE (2005) J Electroanal Chem 579:291

113. Davoodi A, Pan J, Leygraf C, Norgren S (2006) Appl Surf Sci 252:5499

114. Janotta M, Rudolph D, Kueng A, Kranz C, Voraberger H-S, Waldhauser W, Mizaikoff B (2004) Langmuir 20:8634

115. Ballesteros Katemann B, Inchauspe CG, Castro PA, Schulte A, Calvo EJ, Schuhmann W (2003) Electrochim Acta 48:1115

116. Bastos AC, Simões AM, Gonzalez S, Gonzalez-Garcia Y, Souto RM (2005) Prog Org Coat 53:177

117. Souto RM, Gonzalez-Garcia Y, Gonzalez S (2005) Corros Sci 47:3312

118. Toth K, Nagy G, Horrocks BR, Bard AJ (1993) Anal Chim Acta 282:239

119. Gründig B, Wittstock G, Rüdel U, Strehlitz B (1995) J Electroanal Chem 395:143

120. Simões AM, Bastos AC, Ferreira MG, González-García Y, González S, Souto RM (2007) Corros Sci 49:726

121. Ballesteros Katemann B, Schulte A, Calvo EJ, Koudelka-Hep M, Schuhmann W (2002) Electrochem Commun 4:134

122. Baranski AS, Diakowski PM (2004) J Solid State Electrochem $8: 683$

123. Etienne M, Schulte A, Schuhmann W (2004) Electrochem Commun 6:288

124. Zuili D, Maurice V, Marcus P (1998) Proc Electrochem Soc 9726:1013

125. Kunze J, Maurice V, Klein LH, Strehblow H-H, Marcus P (2003) Corros Sci 46:245

126. Zamborini FP, Campbell JK, Crooks RM (1998) Langmuir $14: 640$

127. Lu H, Meng G, Li Y, Wang F (2005) J Mater Sci Technol 21:311

128. Zamborini FP, Crooks RM (1997) Langmuir 13:122

129. Diez-Perez I, Gorostiza P, Sanz F, Muller C (2001) J Electrochem Soc 148:B307

130. Maurice V, Strehblow HH, Marcus P (1998) Proc Electrochem Soc 97-26:902

131. Wapner K, Schoenberger B, Stratmann M, Grundmeier G (2005) J Electrochem Soc 152:E114

132. Williams G, McMurray HN (2001) J Electrochem Soc 148:B377

133. Williams G, McMurray HN, Worsley DA (2002) J Electrochem Soc 149:B154

134. Williams G, McMurray N (2007) Forensic Sci Int 167:102

135. Zerweck U, Loppacher C, Otto T, Grafström S, Eng LM (2007) Nanotechnol 18:084006

136. Han LT, Mansfeld F (1997) Corros Sci 39:199

137. Nazarov A, Thierry D (1998) J Electrochem Soc 145:L39

138. Araoka A, Nishikata A, Tsuru T (2000) Proc Electrochem Soc 99-26:78

139. Wang XY, Li DY (2002) Electrochim Acta 47:3939

140. Femenia M, Canalias C, Pan J, Leygraf C (2003) J Electrochem Soc 150:B274

141. Wang XY, Li DY (2003) Wear 255:836

142. Mahmoud MG, Itoh J, Nagano H, Nakasa K (2004) Zairyo to Kankyo 53:69

143. Nazarov A, Thierry D (2004) Electrochim Acta 49:2717

144. Wang J, Wang Y (2005) Corrosion (Houston, TX, U. S.) 61:264

145. Lobnig RE, Jankoski CA (1998) J Electrochem Soc 145:946

146. Chen ZY, Zakipour S, Persson D, Leygraf C (2004) Corrosion (Houston, TX, U. S.) 60:479

147. Chen ZY, Persson D, Nazarov A, Zakipour S, Thierry D, Leygraf C (2005) J Electrochem Soc 152:B342

148. Li W, Li DY (2006) Acta Mater 54:445 
149. Lobnig RE, Siconolfi DJ, Psota-Kelty L, Grundmeier G, Frankenthal RP, Stratmann M, Sinclair JD (1996) J Electrochem Soc 143:1539

150. Tahara A, Kodama T (2000) Corros Sci 42:655

151. Neufeld AK, Cole IS, Bond AM, Furman SA (2002) Corros Sci 44:555

152. Nazarov AP, Thierry D (2006) Prot Met 42:437

153. Schmutz P, Frankel GS (1998) J Electrochem Soc 145:2285

154. Leblanc P, Frankel GS (2002) J Electrochem Soc 149:B239

155. Juzeliunas E, Leinartas K, Furbeth W, Juttner K (2003) Corros Sci 45:1939

156. Blueher DB, Svensson JE, Johansson LG, Rohwerder M, Stratmann M (2004) J Electrochem Soc 151:B621

157. de Wit JHW (2004) Electrochim Acta 49:2841

158. LeBozec N, Persson D, Thierry D (2004) J Electrochem Soc 151:B440

159. Muster TH, Hughes AE, Harvey TG, Nikpour T, Hardin SG (2004) Mater Forum 28:1243

160. Jia JX, Atrens A, Song G, Muster TH (2005) Mater Corros 56:468

161. Vander Kloet J, Hassel AW, Stratmann M (2005) Z Phys Chem (Muenchen, Ger.) 219:1505

162. Andreatta F, Apachitei I, Kodentsov AA, Dzwonczyk J, Duszczyk J (2006) Electrochim Acta 51:3551

163. Joensson M, Thierry D, LeBozec N (2006) Corros Sci 48:1193

164. McMurray HN, Coleman A, Williams G, Afseth A, Scamens G (2006) Mater Sci Forum 519-521:679

165. Mato S, Alcala G, Woodcock TG, Gebert A, Eckert J, Schultz L (2005) Electrochim Acta 50:2461

166. Yasakau KA, Zheludkevich ML, Lamaka SV, Ferreira MGS (2006) J Phys Chem B 110:5515

167. LeBozec N, Nazarov A, Persson D, Thierry D, Isaacs HS (2001) Proc Electrochem Soc 2001-22:81

168. Kamimura T, Stratmann M (2001) Corros Sci 43:429

169. McMurray HN, Williams G, O’Driscoll S (2001) Proc Electrochem Soc 2001-22:891

170. Wang XY, Li DY (2001) Mater Sci Eng, A A315:158

171. Forget L, Delhalle J, Mekhalif Z (2001) Mater Corros 52:181

172. Campestrini P, Terryn H, Vereecken J, de Wit JHW (2004) J Electrochem Soc 151:B359

173. Campestrini P, Terryn H, Hovestad A, de Wit JHW (2004) Surf Coat Technol 176:365

174. Mekhalif Z, Forget L, Delhalle J (2005) Corros Sci 47:547

175. Zhang X, Sloof WG, Hovestad A, van Westing EPM, Terryn H, de Wit JHW (2005) Surf Coat Technol 197:168

176. Wilson B, Fink N, Grundmeier G (2006) Electrochim Acta 51:3066

177. Andreatta F, Lohrengel MM, Terryn H, de Wit JHW (2003) Electrochim Acta 48:3239

178. Andreatta F, Terryn H, de Wit JHW (2004) Electrochim Acta 49:2851

179. Baeck G, Nazarov A, Thierry D (2005) Corrosion (Houston, TX, U. S.) 61:951

180. Yamawaki M, Suzuki A, Ono F, Yamaguchi K (1997) J Nucl Mater 248:319

181. Feser R, Von Franque O, Siedlarek W (2001) Mater Corros 52:362

182. Li W, Li DY (2005) Acta Mater 53:3871

183. Guessab S, Boyer L, Houze F, Noel S, Schneegans O (2001) Synth Met 118:121

184. Wintterlin J, Trost J, Renisch S, Schuster R, Zambelli T, Ertl G (1997) Surf Sci 394:159

185. Eckhard K, Chen X, Turcu F, Schuhmann W (2006) Phys Chem Chem Phys 8:5359

186. Fernández JL, White JM, Sun Y, Tang W, Henkelman G, Bard AJ (2006) Langmuir 22:10426

187. Fernandez JL, Bard AJ (2003) Anal Chem 75:2967

188. Fernandez JL, Walsh DA, Bard AJ (2005) J Am Chem Soc $127: 357$
189. Fernandez JL, Hurth C, Bard AJ (2005) J Phys Chem B 109:9532

190. Jambunathan K, Hillier AC (2002) J Electroanal Chem 524 525:144

191. Jambunathan K, Shah BC, Hudson JL, Hillier AC (2001) J Electroanal Chem 500:279

192. Jayaraman S, Hillier AC (2003) J Phys Chem B 107:5221

193. Jayaraman SH, Andrew C (2001) Langmuir 17:7857

194. Meier J, Friedrich AK, Stimming U (2002) Faraday Discuss 121:365

195. Meier J, Schiotz J, Liu P, Norskov JK, Stimming U (2004) Chem Phys Lett 390:440

196. MacDiarmid AG, Heeger A (1980) Synth Met 1:101

197. Diaz AF, Kanazawa KK, Gardini GP (1979) J Chem Soc Chem Commun 635

198. Wegner G (1981) Angew Chem Int Ed Engl 20:361

199. Garnier F (1989) Angew Chem Int Ed Engl 28:513

200. Albert KJ, Lewis NS, Schauer CL, Sotzing GA, Stitzel SE, Vaid TP, Walt DR (2000) Chem Rev 100:2595

201. Wang C-Y (2004) Chem Rev 104:4727

202. Weber AZ, Newman J (2004) Chem Rev 104:4679

203. Park S-M (1997) Handbook of organic conducting polymers. Wiley, Chichester

204. Bredas JL, Street GB (1985) Acc Chem Res 18:309

205. Kwak J, Anson FC (1992) Anal Chem 64:250

206. Lee C, Anson FC (1992) Anal Chem 64:528

207. Frank MHT, Denuault G (1993) J Electroanal Chem 354:331

208. Frank MHT, Denuault G (1994) J Electroanal Chem 379:399

209. Denuault G, Frank MHT, Peter LM (1992) Faraday Discuss 94:23

210. Arca M, Mirkin MV, Bard AJ (1995) J Phys Chem 99:5040

211. Gough DA, Leypoldt JK (1979) Anal Chem 51:439

212. Howell JO, Mirkin MV (1984) Anal Chem 56:524

213. Williams ME, Stevensons KJ, Massari AM, Hupp JT (2000) Anal Chem 72:3122

214. Belanger S, Stevensons KJ, Mudakha SA, Hupp JT (1999) Langmuir 15:837

215. Tsionsky M, Bard AJ, Dini D, Decker F (1998) Chem Mater 10:2120

216. Mirkin MV, Fan F-RF, Bard AJ (1992) Science 257:364

217. Fan F-RF, Mirkin MV, Bard AJ (1994) J Phys Chem 98:1475

218. O'Mullane AP, Macpherson JV, Unwin PR, Cervera-Montesinos J, Manzanares JA, Frehill F, Vos JG (2004) J Phys Chem B 108:7219

219. Whitworth AL, Mandler D, Unwin PR (2005) Phys Chem Chem Phys 7:356

220. Zhang L, Barker L, Mandler D, Unwin PR (2003) J Am Chem Soc 125:9312

221. Yang R, Smyrl WH, Evans DF, Hendrickson WA (1992) J Phys Chem 96:1428

222. Ougang M, Huang J-L, Lieber CM (2002) Annu Rev Phys Chem $53: 201$

223. Jeon D, Kim J, Gallagher MC, Willis RF (1992) Science 256:1662

224. Semenikhin OA, Jiang L, Hashimoto K, Fujishima A (1997) Electrochim Acta 42:3321

225. Semenikhin OA, Jiang L, Iyoda T, Hashimoto K, Fujishima A (1996) J Phys Chem 100:18603

226. Lee HJ, Park S-M (2004) J Phys Chem 108:1590

227. Lee HJ, Park S-M (2005) J Phys Chem B 109:13247

228. Wu C-G, Chang S-S (2005) J Phys Chem B 109:825

229. Wuu Y-M, Fan F-RF, Bard AJ (1989) J Electrochem Soc $136: 885$

230. Kranz C, Ludwig M, Gaub HE, Schuhmann W (1995) Adv Mater 7:38

231. Kranz C, Wittstock G, Wohlschlager H, Schuhmann W (1997) Electrochim Acta 42:3105

232. Zhou J, Wipf DO (1997) J Electrochem Soc 144:1202 
233. Borgwarth K, Rohde N, Ricken C, Hallensleben ML, Mandler D, Heinze J (1999) Adv Mater 11:1221

234. Marck C, Borgwarth K, Heinze J (2001) Chem Mater 13:747

235. Actis P, Manesse M, Nunes Kirchner C, Wittstock G, Janel S, Boukherroub R, Szunerits S (2006) Phys Chem Chem Phys 8:4924

236. Lim JH, Mirkin MV (2002) Adv Mater 14:1474

237. Bumm LA, Arnold JJ, Cygan MT, Dunbar TD, Burgin TP, Jones L, Allara DL, Tour JM, Weiss PS (1996) Science 271:1705

238. Noy A, Miller AE, Klare JE, Weeks BL, Woods BW, De Yoreo JJ (2002) Nano Lett 2:109

239. Maynor BW, Filocamo SF, Grinstaff MW, Liu J (2002) J Am Chem Soc 124:522

240. Juhl S, Philips D, Vaia RA, Lyuksyutov SF, Paramonov PB (2004) Appl Phys Lett 85:3836

241. Jang S, Marquez M, Sotzing GA (2004) J Am Chem Soc 126:9476

242. Jegadesan S, Sindhu S, Advincula RC, Valiyaveettil S (2006) Langmuir 22:780

243. Jegadesan S, Taraneka P, Sindhu S, Advincula RC, Valiyaveettil S (2006) Langmuir 22:3807

244. Baba A, Locklin J, Xu R, Advincula R (2006) J Phys Chem B 110:42

245. Ulman A (1991) An introduction to ultrathin organic films: from Langmuir-Blodgett to self-assembly. Academic Press, San Diego

246. Ulman A (1996) Chem Rev 96:1533

247. Xu S, Cruchon-Dupeyrat SJN, Garno JC, Liu G-Y, Kane Jennings G, Yong T-H, Laibinis PE (1998) J Chem Phys 108:5002

248. Edinger K, Gölzhäuser A, Demota K, Wöll C, Grunze M (1993) Langmuir 9:4

249. Kim Y-T, Bard AJ (1992) Langmuir 8:1096

250. Delamarche E, Michel B, Gerber C, Anselmetti D, Guentherodt H-J, Wolf H, Ringsdorf H (1994) Langmuir 10:2869

251. Lüssem B, Müller-Meskamp L, Karthäuser S, Waser R (2005) Langmuir 21:5256

252. Laviron E (1979) J Electroanal Chem 101:19

253. Robinson DB, Chidsey CED (2002) J Phys Chem B 106:10706

254. Smalley JF, Finklea HO, Chidsey CED, Linford MR, Creager SE, Ferraris JP, Chalfant K, Zawodzinsk T, Feldberg SW, Newton MD (2003) J Am Chem Soc 125:2004

255. Mokrani C, Fatisson J, Guerente L, Labbé P (2005) Langmuir $21: 4400$

256. Svobodová L, Snejdárková M, Tóth K, Gyurcsanyi RE, Hianik T (2004) Bioelectrochemistry 63:285

257. Forouzan F, Bard AJ, Mirkin MV (1997) Isr J Chem 37:155

258. Liu B, Bard AJ, Mirkin MV, Creager SE (2004) J Am Chem Soc $126: 1485$

259. Lu X, Zhang L, Li M, Wang X, Zhang Y, Liu X, Zuo G (2006) ChemPhysChem 7:854

260. Boldt F-M, Baltes N, Borgwarth K, Heinze J (2005) Surf Sci 597:51

261. Yamada H, Ogata M, Koike T (2006) Langmuir 22:7923

262. Tour JM, Jones L II, Pearson DL, Lamba JJ, Burgin TP, Whitesides GM, Allara DL, Parikh AN, Atre SV (1995) J Am Chem Soc 117:9529

263. Tanaka S, Yamashita Y (1999) Synth Met 101:532

264. Tans SJ, Verschueren ARM, Dekker C (1998) Nature 393:49

265. Wong EW, Collier CP, Behloradsky M, Raymo FM, Stoddart JF, Heath JR (2000) J Am Chem Soc 122:5831

266. Schreiber F (2000) Prog Surf Sci 65:151

267. Chabinyc ML, Chen X, Holmlin RE, Jacobs H, Skulason H, Frisbie CD, Mujica V, Ratner MA, Rampi MA, Whitesides GM (2002) J Am Chem Soc 124:11730

268. Slowinski K, Slowinska KU, Majda M (1999) J Phys Chem B 103:8544
269. Kushmerick JG, Lazorcik J, Patterson CH, Shashidhar R, Seferos DS, Bazan GC (2004) Nano Lett 4:639

270. Reichert J, Weber HB, Mayor M, von Lohneysen H (2003) Appl Phys Lett 82:4137

271. Reed MA, Zhou C, Muller CJ, Burgin TP, Tour JM (1997) Science 278:252

272. Han W, Durantini EN, Moore TA, Moore AL, Gust D, Rez P, Leatherman G, Seely GR, Tao N, Lindsay SM (1997) J Phys Chem B 101:10719

273. Ishida T, Mizutani W, Akiba U, Umemura K, Inoue A, Choi N, Fujihira M, Tokumoto H (1999) J Phys Chem B 103:1686

274. Mizutani W, Ishida T, Tokumoto H (1999) Jpn J Appl Phys 38:3892

275. Ishida T, Mizutani W, Choi N, Akiba U, Fujihira M, Tokumoto H (2000) J Phys Chem B 104:11680

276. Gorman CB, Carroll RL, Fuierer RR (2001) Langmuir 17:6923

277. Ishida T, Mizutani W, Aya Y, Ogiso H, Sasaki S, Tokumoto H (2002) J Phys Chem B 106:5886

278. Tivanski AV, Walker GC (2005) J Am Chem Soc 127:7647

279. Wold DJ, Haag R, Rampi MA, Frisbie CD (2002) J Phys Chem B 106:2813

280. Beebe JM, Engelkes VB, Miller LL, Frisbie CD (2002) J Am Chem Soc 124:11268

281. Beebe JM, Engelkes VB, Liu J, Gooding JJ, Eggers PK, Jun Y, Zhu X, Paddon-Row MN, Frisbie CD (2005) J Phys Chem B 109:5207

282. Rawlett AM, Hopson TJ, Nagahara LA, Tsui RK, Ramachandran GK, Lindsay SM (2002) Appl Phys Lett 81:3043

283. Fan F-RF, Yang J, Cai L, Price DW, Dirk SM, Kosynki DV, Yao Y, Rawlett AM, Tour JM, Bard AJ (2002) J Am Chem Soc 124:5550

284. Cui XD, Zarate X, Tomfohr J, Sankey OF, Primak A, Moore AL, Moore TA, Gust D, Harris G, Lindsay SM (2002) Nanotechnol 13:5

285. Gomar-Nadal E, Ramachandran GK, Chen F, Burgin T, Rovira CR, Amabilino DB, Lindsay SM (2004) J Phys Chem B 108:7213

286. Lee T, Wang W, Klemic JF, Zhang JJ, Su J, Reed MA (2004) J Phys Chem B 108:8742

287. Tivanski AV, He Y, Borguet E, Liu H, Walker GC, Waldeck DH (2005) J Phys Chem B 109:5398

288. Leatherman G, Durantini EN, Gust D, Moore TA, Moore AL, Stone S, Zhou Z, Rez P, Liu YZ, Lindsay SM (1999) J Phys Chem B 103:4006

289. Datta S, Tian W, Hong S, Reifenberger R, Henderson JI, Kubiak CP (1997) Phys Rev Lett 79:2530

290. Jung TA, Moser A, Hug HJ, Brodbeck D, Hofer R, Hidber HR, Schwarz UD (1992) Ultramicroscopy 42-44:1446

291. Kraemer S, Fuierer RR, Gorman CB (2003) Chem Rev 103:4367

292. Wilhelm T, Wittstock G (2001) Electrochim Acta 47:275

293. Schoer JK, Zamborini FP, Crooks RM (1996) J Phys Chem 100:11086

294. LaGraff JR, Gewirth AA (1995) J Phys Chem 99:10009

295. Wittstock G, Hesse R, Schuhmann W (1997) Electroanalysis 9:746

296. Wittstock G, Schuhmann W (1997) Anal Chem 69:5059

297. Shiku H, Uchida I, Matsue T (1997) Langmuir 13:7239

298. Ciabanu M, Kincaid HA, Jennings GK, Cliffel DE (2005) Langmuir 21:692

299. Evans SD, Ulman A (1990) Chem Phys Lett 170:462

300. Evans SD, Urankar E, Ulman A, Ferris N (1991) J Am Chem Soc 113:4121

301. Robinson GN, Kebabian PL, Freedman A, DePalma V (1997) Thin Solid Films 310:24

302. Saito N, Hayashi K, Sugimura H, Takai O, Nakagiri N (2001) Chem Phys Lett 349:172

303. Hong L, Hayashi K, Sugimura H, Takai O, Nakagiri N, Okada M (2003) Surf Coat Technol 169-170:211

304. Nakagiri N, Sugimura H, Ishida Y, Hayashi K, Takai O (2003) Surf Sci 532-535:999 